University of Pennsylvania Carey Law School

Penn Law: Legal Scholarship Repository

Faculty Scholarship at Penn Law

2002

\title{
Lines in the Sand: The Importance of Borders in American Federalism
}

Seth F. Kreimer

University of Pennsylvania Carey Law School

Follow this and additional works at: https://scholarship.law.upenn.edu/faculty_scholarship

Part of the Constitutional Law Commons, Ethics and Political Philosophy Commons, Jurisprudence Commons, Legal Commons, Legal Theory Commons, and the State and Local Government Law Commons

\section{Repository Citation}

Kreimer, Seth F., "Lines in the Sand: The Importance of Borders in American Federalism" (2002). Faculty Scholarship at Penn Law. 1170.

https://scholarship.law.upenn.edu/faculty_scholarship/1170

This Response or Comment is brought to you for free and open access by Penn Law: Legal Scholarship Repository. It has been accepted for inclusion in Faculty Scholarship at Penn Law by an authorized administrator of Penn Law: Legal Scholarship Repository. For more information, please contact PennlawIR@law.upenn.edu. 


\section{RESPONSE}

\section{LINES IN THE SAND: THE IMPORTANCE OF BORDERS IN AMERICAN FEDERALISM}

\section{SETH F. KREIMER ${ }^{\dagger}$}

The highest praise to which a scholar can aspire is to have one's work accepted in print as a vital insight. But being viewed as a worthy enough participant in debate to be made the subject of careful published criticism by a colleague comes a close second. Professor Rosen offers this latter honor to the work I have done on the subject of extraterritorial regulation. Generously characterizing me as a "prominent scholar," Professor Rosen devotes a good portion of his thoughtful and extensive article to the effort to demonstrate that my earlier work erred in arguing that American constitutional federalism is inconsistent with efforts by states to prosecute their citizens for actions that are in fact legal in the sister states where the actions take place. Professor Rosen and the editors of the University of Pennsylvania Law Review have graciously offered me the opportunity to respond.

Rather than reproduce the arguments I have made in earlier articles in extenso, ${ }^{2}$ I will endeavor to highlight the most important ele-

† Professor of Law, University of Pennsylvania Law School. I am indebted to Leonardo Cuello for invaluable research assistance and to Ned Diver for important and enlightening commentary on this paper. Responsibility for errors, omissions, or misunderstandings, of course, remains mine alone.

'Mark D. Rosen, Extraterritoriality and Political Heterogeneity in American Federalism, 150 U. PA. L. REV. 855, 933 (2002) [hereinafter Rosen, Extraterritoriality]. Professor Rosen is also the author of The Outer Limits of Community Self-Governance in Residential Associations, Municipalities, and Indian Country: A Liberal Theory, 84 VA. L. REV. 1053 (1998) [hereinafter Rosen, Outer Limits].

${ }^{2}$ Those who are interested in the evolution of my thinking on these and related issues may consult Seth F. Kreimer, Federalism and Freedom, 574 ANNALS AM. ACAD. POL. \& SoC. SCI. 66 (2001) [hereinafter Kreimer, Federalism and Freedom]; Matthew D. Adler \& Seth F. Kreimer, The New Etiquette of Federalism: New York, Printz, and Yeskey, 1998 SuP. CT. REv. 71 [hereinafter Adler \& Kreimer, The New Etiquette]; Seth F. Kreimer, Territoriality and Moral Dissensus; Thoughts on Abortion, Slavery, Gay Marriage and Family Values, 16 QUINNIPIAC L. REV. 161 (1996); Seth F. Kreimer, “But Whoever Treasures Freadom ... ": The Right to Travel and Extraterritorial Abortions, 91 MICH. L. REV. 907 (1993) [hereinafter Kreimer, Whoever Treasures Freedom]; Seth F. Kreimer, The Law of Choice and Choice of Law: Abortion, the Right to Travel, and Extraterritorial Regulation in American Fed- 
ments of conflict between our approaches and to indicate the reasons why I continue to maintain my original position. In the course of the discussion, I will touch on Supreme Court developments since the time that $I$ engaged in my original research. This response begins with an overview of the differences between Professor Rosen's perceptions of the nature of American federalism and my own, continues with an analysis of the differences between our understandings of the current caselaw, and concludes with an examination of the philosophical issues between us.

\section{THE NATURE OF AMERICAN FEDERALISM}

\section{A. Areas of Agreement}

It is well to begin with areas where Professor Rosen and I find agreement.

We agree, first of all, that American federalism does in fact leave room for substantial variation of moral visions and legal regimes among states, and that this is a strength of our system. When citizens can choose among and compare the virtues of the permission of assisted suicide in Oregon, ${ }^{8}$ covenant marriage in Louisiana, ${ }^{4}$ medical marijuana in California, ${ }^{5}$ and same-sex unions in Vermont, ${ }^{6}$ we are likely to have a society that is morally richer, practically freer, and personally more fulfilling than if a single inflexible code governed the nation. Second, we agree that citizens by constitutional right do, and morally should, have the opportunity to leave the state polities of which they find themselves members. ${ }^{7}$ Third, we agree that when citi-

eralism, 67 N.Y.U. L. REV. 451 (1992) [hereinafter Kreimer, Law of Choice].

${ }^{3}$ OR. Rev. STAT. ANN. $\$ 127.805$ (Supp. 1998).

${ }^{4}$ LA. REv. STAT. ANN. \$ 9:272 (West Supp. 2002).

${ }^{5}$ CAL. HEALTH \& SAFETy CODE $\$ 11362.5$ (West 2001).

${ }^{6}$ VT. STAT. ANN. tit. 15, $\$ 1202$ (Supp. 2001).

${ }^{7}$ As a matter of positive law, Professor Rosen acknowledges that the heritage of the Articles of Confederation, the Citizenship and Privileges and Immunities Clauses of the Fourteenth Amendment, and the caselaw of the Supreme Court establish a right on the part of citizens of any state to leave that state, and to take up residence in any other state. See Rosen, Extraterritoriality, supra note 1, at 913-14 (discussing Saenz v. Roe, 526 U.S. 489 (1999)). Founded as it is on emigration from other countries, the United States has long taken the position that the right to alter one's citizenship by expatriation is an "inherent and fundamental right." JAMES H. KETTNER, THE DEVELOPMENT OF AMERICAN CITIZENSHIP 1608-1870, at 268-70 (1978); see PETER H. SCHUCK \& ROGERS M. SMITH, CrTIZENSHIP WITHOUT CONSENT 54-56 (1985) (noting a "robust right of expatriation"). The clarification of citizenship in the aftermath of the Civil War brought an explicit recognition by Congress in 1868 that "the right of expatriation is a natural 
zens leave their home states, those states rarely seek to enforce their moral visions by criminally prosecuting their citizens' lawful activities in other states. ${ }^{8}$ States often extend their reach to punish extraterritorial actions that have tangible impacts on the territory over which they are sovereign; a shot fired across the border from South Carolina into Georgia is the classic justification for the exercise of Georgia's criminal authority. But an effort by Georgia to prosecute its citizens for gambling in Nevada is aberrant. Our differences arise in large measure over whether this third fact is a regrettable artifact of misunderstanding the nature of the state's real powers-as Professor Rosen appears to believe-or a legally compelled and normatively desirable characteristic of American federalism, as I maintain.

\section{B. History, Practice, and Structure: Territorial States}

In common understanding, a state's law governs its own territory. Most Americans, when they drive across the border from Pennsylvania to New Jersey, assume that the relevant speed limit becomes New Jersey's, not Pennsylvania's; if offered a seat at a blackjack table in Nevada, they would believe that the question of its legality is governed by Nevada law. And in most cases, they would be right, for, in general, state criminal statutes are territorially limited. Indeed, in most states, explicit provisions of their own constitutions preclude the states from

and inherent right of all people, indispensable to the enjoyment of the rights of life, liberty, and the pursuit of happiness." KETTNER, supra, at 344 (quoting Act of July 27, 1868, ch. 249, 15 Stat. 223 (1868)); see SCHUCK \& SMITH, supra, at 61-62 (describing the enactment of the first Expatriation Act). Within the United States, citizens have a right to determine state citizenship by choosing "the state wherein they reside." U.S. CONST. amend XIV, $\$ 1$.

As a matter of normative political theory, Professor Rosen acknowledges that the opportunity to leave a polity is a precondition to its exercise of legitimate authority. See Mark D. Rosen, Multiple Authoritative Interpreters of Quasi-Constitutional Federal Law: Of Tribal Courts and the Indian Cizil Rights Act, 69 FORDHAM L. REv. 479, 504 (2000) ("People in the original position would agree that an exit right is necessary because without it a polity would reproduce the problem that led them to accommodate political perfectionists in the first place ...."); Rosen, Outer Limits, supra note 1, at 1098 ("[T] he option to choose where you live-what might be called the right of people to 'opt-out' of the environment in which they find themselves and relocate to another-must be a real one." (citation omitted)).

${ }^{8}$ One of the few cases Professor Rosen cites that comes close is Commonwealth $v$. Hartford, No. 95-98 (Ct. Com. Pl. Sullivan County, Pa. Dec. 5, 1996). Rosen, Extraterritoriality, supra note 1 , at 859 n.10. Ms. Hartford's conviction for interfering with the custody of the child's parent (not of aiding in the evasion of Pennsylvania's abortion law) was reversed for failure to provide proper jury instructions on the elements of interference with custody. Commonwealth v. Hartford, No. 00088PHL97 (Pa. Super. Ct. Oct. 28, 1997). 
prosecuting wholly extraterritorial crimes by requiring that juries be drawn from among the geographic community where the alleged crime occurred. ${ }^{9}$

The Federal Constitution is not so explicit, but a series of elements of constitutional structure were framed on the premise that a state's legitimate authority is territorial. Boundaries between states are territorially defined and unalterable; one state cannot be established "within the Jurisdiction" of another without the former state's consent. $^{10}$ The Extradition Clause of Article IV provides that an accused who flees from the state where a crime is committed must be "delivered up [and] removed to the State having Jurisdiction of the Crime;" it it acknowledges that the responsibility and prerogative for punishment rests with the state within which the crime occurred. ${ }^{12}$ And other provisions are at odds with the notion that state residents carry a personal law with them when they venture into other states. ${ }^{13}$

${ }^{9}$ See Appendix (listing such provisions). While such vicinage provisions are variously worded, their common import is to require trial by a jury of the jurisdiction "where the crime was committed." A home state could not try a crime committed in a host state since the constitutional provisions would mandate a jury of the foreign state.

${ }^{10}$ U.S. ConST. art. IV, $\$ 3$, cl. 1 .

${ }^{11}$ Id. $\$ 2, \mathrm{cl} .2$.

${ }^{12}$ See Letter from James Madison to Edmund Randolph (Mar. 10, 1784) ("Unless Citizens of one State transgressing within the pale of another be given up to be punished by the latter, they cannot be punished at all ...."), reprinted in 4 THE FOUNDERS' CONSTITUTION 517 (Philip B. Kurland \& Ralph Lerner eds., 1987). Madison was discussing the demand by South Carolina that Virginia extradite a Virginia citizen for an offense in South Carolina. His assumption was that Virginia would have no authority to punish its citizens for extraterritorial wrongs.

Professor Rosen's counterexample of an extradition by Michigan on the basis of a crime that originated extraterritorially in Illinois, but came to fruition in Michigan, is not to the contrary. See Rosen, Extraterritoriality, supra note 1, at 864-65 (discussing Strassheim v. Daily, 221 U.S. 280 (1911)). Prosecution in such cases is consistent with the understanding of the Framers of the Constitution: it is the consummation of the crime "within the pale" of Michigan that provides the predicate for extradition.

${ }^{13}$ The understanding that a citizen of one state venturing into another state would be bound by the local law motivated the adoption of Article IV's Privileges and Immunities Clause; it was necessary to guarantee that the host would not use its exclusive power to the detriment of visitors from other states in the Union. For example, the Court in Paul v. Virginia stated:

[W]ithout some provision of the kind removing from the citizens of each State the disabilities of alienage in the other States... the Republic would have constituted little more than a league of States; it would not have constituted the Union that now exists.... It was not intended by the provision to give to the laws of one State any operation in other States. They can have no such operation, except by the permission, express or implied, of those States. The special privileges which they confer must, therefore, be enjoyed at home, unless the assent of other States to their enjoyment therein be given. 
The guaranty of a jury local to the situs of the alleged crime was embodied in Article III's requirement that for federal offenses "the trial of all Crimes ... . shall be held in the State where said Crimes shall have been committed." Antifederalist fears "that Article III's provision failed to preserve the common-law right to be tried by a "jury of the vicinage' . . . furnished part of the impetus for introducing amendments to the Constitution that ultimately resulted in the jury trial provisions of the Sixth [Amendment]." ${ }^{, 15}$ The Sixth Amendment now guarantees, "In all criminal prosecutions, the accused shall enjoy the right to a speedy and public trial, by an impartial jury of the State and district wherein the crime shall have been committed ..." $\mathrm{n}$ strong line of cases holds that the Sixth Amendment is incorporated against the states, ${ }^{17}$ and thus functions as an effective bar to wholly ex-

75 U.S. (8 Wall.) 168, 180-81 (1868).

The Fugitive Slave Clause was tacit recognition that, absent constitutional constraint, local law could emancipate slaves who found their way across borders whatever the rules in their home state. See, e.g., Prigg v. Pennsylvania, 41 U.S. (16 Pet.) 536, 611 (1842) (Story, J.) ("[I]f the [C]onstitution had not contained [the Fugitive Slave Clause] every non-slave-holding state in the Union would have been at liberty to have declared free all runaway slaves coming within its limits...."); id. at 647 (Wayne, J., concurring) (noting that absent the Fugitive Slave Clause, escaped slaves could be freed in the North).

At the Constitutional Convention, Charles Pinkney first sought to qualify rights of the host state under the Privileges and Immunities Clause by including a protection "in favor of property in slaves," an effort that was rejected. NOTES OF DEBATES IN THE FEDERAL CONVENTION OF 1787 RePORTED BY JAMES MADISON 545 (A. Koch ed., 1966). He then, along with Pierce Butler, sought to insert the Fugitive Slave Clause. Id. This effort succeeded the next day. Id. at 552 .

${ }^{14}$ U.S. CONST. art. III, $\$ 2$, cl. 3.

${ }^{15}$ Williams v. Florida, 399 U.S. 78, 93-94 (1970).

${ }^{16}$ U.S. CONST. amend. VI. For a recent account of the evolution of the vicinage right, the importance of local juries as bulwarks of liberty, and the hostility of early Americans to extraterritorial prosecution at the time of the framing of the Constitution, see Steven A. Engel, The Public's Vicinage Right: A Constitutional Argument, 75 N.Y.U. L. REV. 1658, 1685 (2000): “Like the English commentators, the Continental Congress understood the vicinage presumption to be a structural property of the 'great right', one that served not only the interests of the defendant, but those of the community as well." See also United States v. Cabrales, 524 U.S. 1, 7, 9-10 (1998) (dismissing a Missouri indictment on conspiracy and money laundering charges because alleged charges occurred wholly within Florida and explaining vicinage requirements).

${ }^{17}$ See, e.g., Alvarado v. State, 486 P.2d 891, 897 (Alaska 1971) (holding the Sixth Amendment applicable to states in requiring an impartial jury); Patterson v. Balkcom, 266 S.E.2d 179, 180-81 (Ga. 1980) (applying the Sixth Amendment to vicinage within Georgia); Hayes v. Commonwealth, 698 S.W.2d 827, 830 (Ky. 1985) (construing the Sixth Amendment to forbid state's prosecution of out-of-state theft); State v. Butler, 724 A.2d 657, 660 (Md. 1999) (finding the Sixth Amendment is at the root of bars against extraterritorial criminal prosecution by the state); State v. Smith, 421 N.W.2d 315, 318-19 (Minn. 1988) (finding the Sixth Amendment preserves the territorial ju- 


\section{traterritorial state prosecutions.}

As I showed at exhaustive (and exhausting) length previously, ${ }^{18}$ review of the historical context, contemporaneous commentary and caselaw demonstrates that the understanding of the scope of the sovereign power of states before the middle of the twentieth century did not include the right to regulate citizens extraterritorially. Even in the case of the most serious moral commitments, under generally accepted law a state could not impose those commitments on its citizens within territory of neighboring states whose commitments differed. Before the Civil War, for example, Justice Marshall was voicing the common constitutional wisdom when he observed in Cohens v. Virginia that it is "clear, that a State legislature, the State of Maryland, for example, cannot punish those who, in another State, conceal a felony committed in Maryland." ${ }^{n 19}$ This was the virtually unanimous opinion of judicial authority in every state between the founding of the Repub-

risdiction principle and refusing jurisdiction over murder when no elements were proven to have occurred in Minnesota); Miss. Publishers Corp. v. Coleman, 515 So. 2d 1163,1166 (Miss. 1987) (denying writ of mandamus and affirming closure order pursuant to the Sixth Amendment vicinage requirement); State v. Preite, 564 P.2d 598, 599-602 (Mont. 1977) (vacating grand larceny convictions because prosecution failed to prove venue pursuant to Sixth Amendment requirement); State v. Darroch, 287 S.E.2d 856, 860-65 (N.C. 1982) (holding that a state may take jurisdiction in accord with the Sixth Amendment when the "principal felony" occurs in-state); State v. Beuke, 526 N.E.2d 274, 289 (Ohio 1988) (recognizing sufficient elements of murder were present in a case tried in Ohio when death ensued in Indiana and holding that the Sixth Amendment was not violated); State v. Harrington, 260 A.2d 692, 698 (Vt. 1969) ("In the federal jurisdiction, if a crime is committed partly in one district and partly in another, the offender may be tried in either district .... We think the Sixth Amendment applies to interstate criminal jurisdiction with the same force and effect."); $c f$. State v. Morgan, 559 N.W.2d 603, 609 (lowa 1997) ("After the Sixth Amendment was made applicable by the Fourteenth Amendment, there is no reason to think any narrower requirement would be applicable to the states.").

I must acknowledge that the authority here is not unanimous. Most recently, see, for example, Price v. Superior Court, 25 Cal. 4th 1046, 1057-70, cert. denied, 122 S. Ct. 626 (2001), holding, in a situation involving venue for in-state crimes, that the Sixth Amendment does not bind the states and citing cases in support of that proposition. On the other hand, the most recent scholarly account of the question concludes:

The arguments that the Fourteenth Amendment does not incorporate the Vicinage Clause are particularly unconvincing. Those courts that have rejected incorporation have done so because they have found that the vicinage right is not "fundamental" to a fair trial.... There is little doubt that the Founders believed that the protection granted to the accused by the Vicinage Clause was fundamental to a fair trial. Indeed, the Founders fought for the vicinage right at every stage in their struggle for independence.

Engel, supra note 16, at 1707 (citations omitted).

${ }_{18}^{18}$ Kreimer, Law of Choice, supra note 2, at 46472.

19 U.S. 120, 191, 6 Wheat. 264, 426 (1821). 
lic and the Civil War.

Within a decade after the Fourteenth Amendment's adoption in 1868 , the Supreme Court began to read the territorial restrictions on state sovereignty into the definition of due process. At the turn of the century, the Supreme Court struck down Louisiana's attempt to punish its citizens for making offensive insurance contracts in New York on the ground that it "prohibits an act which under the Federal Constitution the defendants had a right to perform.... [The state's] power does not and cannot extend to prohibiting a citizen from making contracts ... outside of the limits and jurisdiction of the State."20 Although the Supreme Court qualified this limitation by allowing prosecution of "[a]cts done outside a jurisdiction, but intended to produce and producing detrimental effects within it," effects were tangible and direct results adverse to the public order of the prosecuting jurisdiction, not the diffuse butterfly's wings effects on "public norms" that Professor Rosen would use to justify prosecution. Professor Rosen's laments regarding territorial limitations were echoed in the pleas of Louisiana's court in Allgeyer that extraterritorial prosecution was necessary to save "the sovereignty of the State" from "mockery." The Supreme Court unanimously rejected those pleas in Allgeyer and regularly maintained that rejection. ${ }^{23}$

I do not understand Professor Rosen to question my reading of this history, for he does not address it. Rather, he apparently maintains that modern caselaw has rendered earlier law irrelevant. Even if

${ }^{20}$ Allgeyer v. Louisiana, 165 U.S. 578, 591 (1897).

${ }^{21}$ Ford v. United States, 273 U.S. 593, 620, 624 (1927) (extraterritorial conspiracy to import liquor into United States); Strassheim v. Daily, 221 U.S. 280, 285 (1911) (extraterritorial scheme directed to defraud state government on bids within the state).

22165 U.S. at 585.

${ }^{23}$ See Home Ins. Co. v. Dick, 281 U.S. 397, 411 (1930) (ruling that Texas cannot affect the terms of a contract entered into by a Texas resident in Mexico without violating due process); Fid. \& Deposit Co. v. Tafoya, 270 U.S. 426, 436 (1926) (striking down a statute seeking to prohibit out-of-state payments by corporations doing business in New Mexico); St. Louis Cotton Compress Co. v. Arkansas, 260 U.S. 346, 347, 349 (1922) (striking down a statute imposing a tax upon persons placing insurance extraterritorially); N.Y. Life Ins. Co. v. Dodge, 246 U.S. 357, 367-77 (1918) (ruling that a state cannot control contract entered into by a resident and a foreign corporation in a foreign state); W. Union Tel. Co. v. Brown, 234 U.S. 542, 546-47 (1914) (ruling that a state statute cannot impose tort liability for acts outside of state territory in the District of Columbia); N.Y. Life Ins. Co. v. Head, 234 U.S. 149, 161 (1914) (“[I]t would be impossible to permit the statutes of Missouri to operate beyond the jurisdiction of that State and in the State of New York ... without throwing down the constitutional barriers by which all the States are restricted within the orbits of their lawful authority ...."). 
there has been an evolution away from territorial limitations, and as I discuss below, the evolution has not gone as far as Professor Rosen believes, the unbroken rejection of extraterritorial state-enforced moralism for the first $\mathbf{1 5 0}$ years of the Republic retains relevance in three dimensions.

First, the historical practice and understanding of the territorial limits of state regulation inform the construction of contemporary constitutional claims. For a wing of the Court led by Justice Scalia, at least, the understandings in place at the time of the adoption of the Fourteenth Amendment have been crucial guideposts in construing the demands of due process. ${ }^{24}$

Second, the historical understanding of the limits of state power suggests that a claim that states have "retained" authority under the Tenth Amendment to regulate extraterritorially is weakly based: if the states were not understood at the time of the framing to have authority to regulate activities in other states, it is hard to claim that they "retained" that authority.

Third, the fact that the American polity operated with reasonable success under a territorialist regime-and indeed with greater normative diversity than obtains currently-raises questions about Professor Rosen's claim that a territorially based system would "cripple" the possibilities for the normative benefits of federalism. ${ }^{26}$

\section{The Virtues of Federalism}

Professor Rosen and I agree that one of the virtues of the system of American federalism is its capacity to further a variety of collective

${ }^{24}$ See, e.g., Honda Motor Co. v. Oberg, 512 U.S. 415, 434 n.12 (1994) (relying on the nineteenth-century practice rather than the eighteenth-century practice even though judicial deference to verdicts was stronger earlier); Burnham v. Superior Court of Cal., 495 U.S. 604, 611 (1990) (noting that 1868, the year of the passage of the Fourteenth Amendment, is "the crucial time" for the Court's analysis); Michael H. v. Gerald D., 491 U.S. 110, 127 n.6 (1989) (relying on the state of the law "at the time the Fourteenth Amendment was ratified"); Sun Oil Co. v. Wortman, 486 U.S. 717, 724-27, 730 (1988) (relying on ideas at the time the Fourteenth Amendment was adopted and the fact that those ideas have been relatively unchallenged since the adoption to find the due process challenge "entirely without substance.").

${ }_{25}^{25 e}$, e.g., U.S. Term Limits, Inc. v. Thornton, 514 U.S. 779, 802 (1999) (“[The Tenth] Amendment could only 'reserve' that which existed before."). In the interests of full disclosure, I must acknowledge that Term Limits was a 5-4 decision, and the dissenting Justices adopted a default rule allowing the states any powers not affirmatively forbidden by the Federal Constitution. Id. at 926 (Thomas, J., dissenting).

${ }^{26}$ Rosen, Extraterritoriality, supra note 1, at 856. 
purposes. ${ }^{27}$ Citizens of Utah can establish a polity that furthers traditional values of family and social order, while citizens of Vermont can simultaneously embed a sense of individualism and pluralism in their political structure. Our society is richer for the existence of both polities. The Supreme Court's federalism decisions recognize these virtues in their praising of self-government, responsiveness, and the pluralistic potential of the "laboratories of the states." 28

But the Supreme Court's jurisprudence of federalism does not end with collective virtues; in recent years, the Justices have regularly recognized that one of the key values of American federalism is its capacity to "preserve freedom." 29 By "freedom," the Supreme Court does not mean merely the collective freedom of state polities from federal constraint, but the individual liberties of citizens, and the openness of American society that flows from those liberties. The variation between states is desirable because it provides an opportunity for individual citizens to mold identities and choose their futures, and because an open national community follows from this right to experimentation. This characteristic of federalism does not loom large in Professor Rosen's account, for he appears to see the signal virtue of federalism as its indifference between regimes of freedom and those of perfectionist morality. ${ }^{30}$ But this is neither the view of the Su-

${ }^{27}$ See id. at 882 (" $[\mathrm{O}]$ ne of federalism's great merits [is] the space it provides for rich political heterogeneity at the subfederal levels of government.").

${ }_{28}$ See New State Ice Co. v. Liebmann, 285 U.S. 262, 311 (1932) (Brandeis, J., dissenting) ("It is one of the happy incidents of the federal system that a single courageous State may, if its citizens choose, serve as a laboratory; and try novel social and economic experiments without risk to the rest of the country."); see also, e.g., Adler \& Kreimer, The New Etiquette, supra note 2, at 77-82 (discussing the values of federalism); Kreimer, Federalism and Freedom, supra note 2, at 67 ("[T] he argument for devolution of power to state and local governments in contemporary cases regularly relies on claims about the virtues of federalism as a means of achieving other values.").

${ }^{29}$ See Coll. Sav. Bank v. Fla. Prepaid Postsecondary Educ. Expense Bd., 527 U.S. 666, 689 (1999) (Scalia, J.) (discussing the "protection of liberty" as a focus of federalism); Printz v. United States, 521 U.S. 898, 921 (1997) (Scalia, J.) ("Th[e] separation of the two spheres is one of the Constitution's structural protections of liberty."); United States v. Lopez, 514 U.S. 549, 576 (1995) (Kennedy, J., concurring) ("[I]t was the insight of the framers that freedom was enhanced by the creation of two governments, not one."); New York v. United States, 505 U.S. 144, 181 (1992) (O'Connor, J.) (" $[T]$ he Constitution divides authority between federal and state governments for the protection of individuals."); Gregory v. Ashcroft 501 U.S. 452, $458-59$ (1991) (O'Connor, J.) (" $[\mathrm{A}]$ healthy balance of power between the States and the Federal government will reduce the risk of tyranny and abuse from either front."); Coleman v. Thompson, 501 U.S. 722, 759 (1991) (Blackmun, J., dissenting) ("[F]ederalism secures to citizens the liberties that derive from the diffusion of sovereign power.").

${ }^{30}$ See Rosen, Extraterritoriality, supra note 1, at 911-13 (advocating a "hard" as op- 
preme Court nor that of the Framers. American federalism is not indifferent in the contest between liberty and order; it is as a "double security" against government infringements on freedom that the Court is solicitous of state prerogatives. ${ }^{31}$

Federalism preserves freedom in part by the constitutionally protected character of emigration rights: a citizen of Texas ${ }^{32}$ who finds that state's prohibitions on same sex relations too onerous can move to Vermont, while a citizen of New York whose desire to own assault weapons is unrealizable can move to Montana. Neither Texas nor New York can prevent the emigration; neither Vermont nor Montana can refuse the immigrants. ${ }^{33}$

In the same way, federalism preserves freedom when the gay man in Texas or the gun enthusiast in New York partakes of the liberties of Vermont, or California, or Montana on a temporary basis, and the former protection is not a substitute for the latter. ${ }^{34}$ The possibility of sampling the liberties of sister states offers a continual challenge to justify the decision of the home state to deny those liberties, and a security against the efforts of any faction to capture a state's authority in order to impose its own enthusiasms on unwilling minorities. In my view, what Professor Rosen denigrates as "travel-evasion" parcel of the promise of American federalism: that each citizen may take advantage of the liberties offered by any state.

An extraterritorial statute raises a final issue of freedom. One of

posed to "soft" regime of legal pluralism).

${ }^{31}$ The Court regularly cites the characterization in THE FEDERALIST NO. 51 (James Madison) of federalism as a "double security" for the "rights of the people" and the promise of liberty. E.g., Printz v. United States, 521 U.S. 898, $921-22$ (1997); United States v. Lopez, 514 U.S. 549, 576 (1994) (Kennedy, J., concurring); Gregory v. Ashcroft, 501 U.S. 452, 459 (1991).

${ }^{32}$ While Georgia, home of Bowers $v$. Hardwick, 478 U.S. 186 (1986), has determined that its constitutional right of privacy protects against state prosecution of "sodomy" in Powell v. State, 510 S.E.2d 18, 26 (Ga. 1998), the state of Texas stands firm in its efforts to criminalize sexual relations between those of the same sex, Lawrence v. State 41 S.W.3d 349, 362 (Tex. App. 2001).

${ }_{93}$ See Saenz v. Roe, 526 U.S. 489, 492 (1999) (striking down a California statute limiting welfare benefits to new residents of the state); Shapiro v. Thompson, 394 U.S. 618,622 (1969) (striking down welfare limitation statutes in Connecticut, Pennsylvania, and the District of Columbia); Edwards v. California, 314 U.S. 160, 170-71 (1941) (finding unconstitutional a California statute which criminalized bringing into the state any nonresident indigent person); Crandall v. Nevada, 73 U.S. (6 Wall.) 35,49 (1868) (holding unconstitutional a tax imposed on leaving the state).

${ }^{34}$ Indeed, it is often those who are most in need of protection who will be least able to take advantage of the emigration right which Professor Rosen would recognize.

${ }^{35}$ Rosen, Extraterritoriality, supra note 1, at 856. 
the elements of a legal system that supports the capacity of citizens to frame and follow their own ends is its public character and predictability. A citizen who knows that when she crosses the boundary between Pennsylvania and New Jersey, she moves from Pennsylvania's law to New Jersey's, can plan her life with some precision to comply with legal obligations. By contrast, under Professor Rosen's scheme, the citizen who travels always must be aware of not one but two or more systems of criminal law as she travels, the applicability of which will vary depending on the degree of "state interest" conflicting or shared between the relevant states. This is a recipe not for freedom but for fear.

\section{The Nature of Citizenship}

Finally, Professor Rosen and I differ on the meaning of American citizenship. For him there is a "dialectic" between state citizenship and federal citizenship. ${ }^{36}$ In Professor Rosen's view, the woman who resides in Pennsylvania, but seeks an abortion in New Jersey, travels inescapably as a Pennsylvania citizen, and any effort to take advantage of the liberties offered by New Jersey or another neighboring state is an improper evasion of her duties as a Pennsylvanian. A doctrine that facilitates her efforts pays insufficient homage to the importance of state citizenship.

To my mind, this interpretation is both descriptively inaccurate and historically obtuse. At the time the United States was founded, one could conceive of American citizenship as derived from a more basic identification with each of the component states, but the time has long past when the "United States of America" was a plural construction. One of the areas of disagreement surrounding the Civil War was precisely the question of whether state or federal citizenship was primary. Proponents of union maintained that national citizenship was a freestanding allegiance; proponents of states' rights maintained that national citizenship existed only insofar as the citizen could claim state citizenship. As a political matter, the Civil War resolved the issue by force of arms, and the resolution was embodied in the Citizenship Clause of the Fourteenth Amendment: persons born or naturalized in the United States are indissolubly citizens of the United States, and only derivatively or contingently citizens of the "State wherein they reside." After adoption of the Fourteenth

\footnotetext{
${ }^{36}$ Rosen, Extraterritoriality, supra note 1 , at 910.

${ }^{97}$ U.S. CONST. amend. XIV, § 1.
} 
Amendment, United States citizenship is "paramount and dominant instead of being subordinate and derivative. ${ }^{38}$

This conclusion is mirrored in the self-understanding of American citizens. At the time of the Civil War, Robert E. Lee resigned his federal commission, and renounced his oath of allegiance because as a "Virginian" he could not bear to honor that oath. It is hard today to find a citizen of the United States who conceives of her primary identity as a "Virginian" or a "Pennsylvanian" or an "Oregonian," rather than an "American," and our nation is stronger for this fact.

In my view, it is precisely the fact that a resident of Pennsylvania comes to New Jersey as an American citizen that entitles her without blame to take advantage of the "privileges and immunities" offered by New Jersey, whether to wager on games of chance or to end an unwanted pregnancy. This does no violence to the authority of Pennsylvania within its boundaries but recognizes that the primary moral community to which we all owe allegiance is that of the United States of America.

\section{The MESSAge of MODERn CASELAW}

\section{A. Sovereignty and Due Process}

Professor Rosen believes that modern caselaw upholds the proposition that a state may punish its citizens for any violations of its norms anywhere in the world. ${ }^{39}$ I have previously argued that, notwithstanding the acceptance of extraterritorial federal prosecutions, the more modern cases accept wholly extraterritorial criminal prosecution by states only in circumstances where there is no competing legal permis-

${ }^{38}$ Selective Draft Law Cases, 245 U.S. 366, 389 (1918). In arguing for the adoption of the Fourteenth Amendment, Congressman Reverdy Johnson said:

[A]s it now stands[,] .. [w]ho is a citizen of the United States is an open question. The decision of the courts and the doctrine of the commentators is, that every man who is a citizen of a State becomes ipso facto a citizen of the United States; but there is no definition as to how citizenship can exist in the United States except through the medium of a citizenship in a State.

CONG. GLOBE, 39th Cong., 1st Sess. 2893 (1866) (statement of Rep. Johnson); see also Edwards v. California, 314 U.S. 160, 182 (1941) (Jackson, J., concurring) ("This clause was adopted to make United States citizenship the dominant and paramount allegiance among us."); Hague v. Comm. for Indus. Org., 307 U.S. 496, 510 (1939) (Roberts, J.) ("The first sentence of the Amendment settled the old controversy as to citizenship.... Thenceforward citizenship of the United States became primary and citizenship of a State secondary.").

${ }^{39}$ See Rosen, Extraterritoriality, supra, note 1, at 944-45 (citing several state cases and the dual sovereignty doctrine). 
sion granted by the sister state where the conduct occurs and where there is some concrete impact on the territorial interests of the prosecuting state. Federal relations to other nations are simply not the same as relations between states that are bound by the comity imposed by the constitution.

Skiriotes $v$. Florida, the only case either of us has found in which the U.S. Supreme Court upholds a state prosecution for wholly extraterritorial conduct solely on the basis of citizenship, has broad language regarding the extraterritorial authority of a state over its citizens. ${ }^{40}$ But in fact the opinion upheld the prosecution based on acts on the high seas, where no competing state sovereignty could be interposed. ${ }^{41}$ The opinion explicitly relies on the proposition articulated by Justice Holmes in The Hamilton: "'the bare fact of the parties being outside the territory in a place belonging to no other sovereign would not limit the authority of the State, as accepted by civilized theory. ${ }^{, 42}$

By contrast, Nielsen v. Oregon, ${ }^{43}$ as Professor Rosen acknowledges, is directly inconsistent with his preferred schema. That case reversed as unconstitutional Oregon's effort to prosecute Nielsen for fishing with a "purse net," in a fashion authorized by the laws of Washington, in waters over which Washington and Oregon had concurrent jurisdiction. ${ }^{44}$ By its terms Nielsen states that when "the opinion of the legislatures of the two States is different ... the one State cannot enforce its opinion against that of the other, at least as to an act done within the

${ }^{40} 313$ U.S. 69,78 (1941).

${ }^{41}$ Id. at 77.

${ }^{42} I d$. at 78 (emphasis added) (quoting The Hamilton, 207 U.S. 398, 403 (1907)). For Justice Holmes, who wrote both The Hamilton and Strassheim v. Daily, 221 U.S. 280 (1911), upon which Professor Rosen relies, the italicized qualification was no accident. As Holmes articulated the matter in another case:

[I]n regions subject to no sovereign, like the high seas, or to no law that civilized countries would recognize as adequate, such countries may treat some relations between their citizens as governed by their own law, and keep to some extent the old notion of personal sovereignty alive.... But the general and almost universal rule is that the character of an act as lawful or unlawful must be determined wholly by the law of the country where the act is done. ... For another jurisdiction, if it should happen to lay hold of the actor, to treat him according to its own notions rather than those of the place where he did the acts, not only would be unjust, but would be an interference with the authority of another sovereign, contrary to the comity of nations, which the other state concerned justly might resent.

Am. Banana Co. v. United Fruit Co., 213 U.S. 347, 355-56 (1909).

212 U.S. 315 (1909)

${ }^{44} I d$. at 316 . 
limits of that other State. ${ }^{45}$

Professor Rosen maintains that Heath v. Alabama ${ }^{46}$ effectively overrules Nielsen, quoting language from Heath in which the Court says that "Nielsen is limited to its unusual facts." ${ }^{47}$ As I discuss below, ${ }^{48}$ Professor Rosen is intrigued with the question of whether the analysis of extraterritoriality in Bigelow v. Virginia is "holding" or "dictum.", Yet his discussion of Heath is somewhat cavalier in eliding the fact that the language he quotes is directed not to Nielsen's holding - which he seeks to discredit-but to the observation that Nielsen "indicates ... in dicta, that where States have concurrent jurisdiction over a criminal offense, the first State to prosecute thereby bars prosecution by any other State"-a point of tangential relevance to our disagreement. ${ }^{50}$

The Heath Court goes on to quote with approval from Nielsen's holding: "It is enough to decide, as we do, that for an act done within the territorial limits of the State of Washington under authority and license from that State one cannot be prosecuted and punished by the State of Oregon." ${ }^{51}$ It holds Nielsen inapplicable, however, to "prosecutions for offenses proscribed by both States." In the situations that divide Professor Rosen and me, the "offense" is not "proscribed by both states;" like the defendant in Nielsen, and unlike the defendant in Heath, the citizen of the home state is acting "under license from" the territorial host state. It is thus hard to read Heath as overruling Nielsen's bar to Professor Rosen's regime of extraterritorial moralism.

States have been reluctant to assert extraterritorial moralism by criminal prosecution in general, and still more chary of seeking to prosecute conduct that is sanctioned by the laws of the state where it occurs. As a result, we have had relatively little discussion by the Supreme Court of the status of the efforts that Professor Rosen would foster. Indeed, as best either of us can tell, the sole direct modern discussion of the issue is contained in a case growing out of the early phases of the modern constitutional controversy over abortion. In Bigelow $v$. Virginia, Virginia sought to prosecute the editor of a Virginia

\footnotetext{
4.5. Id. at 321.

474 U.S. 82 (1985).

${ }^{47}$ Rosen, Extraterritoriality, supra note 1, at 953 (quoting Heath, 474 U.S. at 91).

48 Infra notes 57-61 and accompanying text.

${ }^{49}$ Rosen, Extraterritoriality, supra note 1, at 891.

${ }^{50}$ Heath, 474 U.S. at 91 (emphasis added).

${ }^{51}$ Id. (quoting Nielson v. Oregon, 212 U.S. 315, 321 (1909)).

${ }^{52}$ Id
} 
newspaper for publishing an advertisement for abortion services that were-at the time-legal in New York, but illegal in Virginia. ${ }^{53}$ The Supreme Court reversed the conviction on the ground that, after "assessing the First Amendment interest at stake and weighing it against the public interest allegedly served by the regulation," Virginia's prosecution was unconstitutional. ${ }^{54}$ Justice Blackmun's analysis began as follows:

[T] he placement services advertised in appellant's newspaper were legally provided in New York at that time. The Virginia Legislature could not have regulated the advertiser's activity in New York, and obviously could not have proscribed the activity in that State. Huntington v. Attrill, 146 U.S. 657, 669 (1892). Neither could Virginia prevent its residents from traveling to New York to obtain those services or, as the State conceded, Tr. of Oral Arg. 29, prosecute them for going there. See United States v. Guest, 383 U.S. 745, 757-759 (1966); Shapiro v. Thompson, 394 U.S. 618, 629-631 (1969); Doe v. Bolton, 410 U.S., at 200 . Virginia possessed no authority to regulate the services provided in New York-the skills and credentials of the New York physicians and of the New York professionals who assisted them, the standards of the New York hospitals and clinics to which patients were referred, or the practices and charges of the New York referral services.

A State does not acquire power or supervision over the internal affairs of another State merely because the welfare and health of its own citizens may be affected when they travel to that State. It may seek to disseminate information so as to enable its citizens to make better informed decisions when they leave. But it may not, under the guise of exercising internal police powers, bar a citizen of another State from disseminating information about an activity that is legal in that State.

Later in the opinion, he continued:

The State, of course, has a legitimate interest in maintaining the quality of medical care provided within its borders. Barsky $v$. Board of Regents, 347 U.S. 442, 451 (1954). No claim has been made, however, that this particular advertisement in any way affected the quality of medical services within Virginia. As applied to Bigelow's case, the statute was directed at the publishing of informative material relating to services offered in another State and was not directed at advertising by a referral agency or a practitioner whose activity Virginia had authority or power to regulate.

To be sure, the agency-advertiser's practices, although not then illegal, may later have proved to be at least "inimical to the public interest" in New York. S.P.S. Consultants, Inc. v. Lefkowitz, 333 F. Supp. 1373, 1378

421 U.S. 809, $811-13$ (1975).

${ }^{54}$ Id. at $826,826-29$.

${ }^{55}$ Id. at 822-25 (emphases added) (footnotes omitted). 
(SDNY 1971). But this development would not justify a Virginia statute that forbids Virginians from using in New York the then legal services of a local New York agency. Here, Virginia is really asserting an interest in regulating what Virginians may hear or read about the New York services. It is, in effect, advancing an interest in shielding its citizens from information about activities outside Virginia's borders, activities that Virginia's police powers do not reach. This asserted interest, even if understandable, was entitled to little, if any, weight under the circumstances. ${ }^{56}$

Professor Rosen, following Professor Regan, engages in a lengthy effort to show that the rejection of Virginia's extraterritorial power in Bigelow should be characterized as obiter dicta. ${ }^{57}$ The substance of his argument seems to be that because the Bigelow Court could have reached the same result by relying solely on a "principle that a state may not control its citizens' knowledge of what activities are permissible in other states, ${ }^{58}$ it did in fact rely solely on that principle.

But the opinion did not limit itself to Professor Rosen's principle. Fairly read, as part of its multifactor balancing discussion, Bigelow evaluated Virginia's interest in preventing its citizens from obtaining abortions in New York and rejected the proposition that the state's police powers extend to precluding its citizens from taking advantage of the moral climate of neighboring states.

Certainly, this is the understanding of then-Justice Rehnquist's dissent in Bigelow, which attacked what he characterized as the majority's "major premise that Virginia could not regulate the relations of the advertiser with its residents since these occurred in New York." ${ }^{59}$ Lower courts, when confronted with the issue have held as much. ${ }^{60}$ As

${ }^{56} I d$. at 827-28 (first and fourth emphases added) (footnote omitted).

${ }^{57}$ Rosen, Extraterritoriality, supra note 1, at 891-94.

${ }^{58}$ Id. at 893 . He also suggests that the Bigelow discussion should be devalued because it "did not give careful consideration to the extent of a state's extraterritorial powers" and did not discuss Professor Rosen's favorite cases. Id. In fact, as the opinion notes, Virginia conceded it had no extraterritorial powers to regulate its citizens' abortions in New York, supra text accompanying note 55, and the cases which Professor Rosen cites were adduced by Justice Rehnquist's dissent attacking what he characterized as the majority's major premise. See Bigelow, 421 U.S. at 834 n.2 (Rehnquist, J., dissenting) (citing Skiriotes and Strassheim in support of his disagreement with the limitations on states' extraterritorial power as found by the majority). The fact that Justice Blackmun did not reply in detail may mean that Justice Blackmun is not craftsmanlike; it hardly means that what Justice Rehnquist characterized as the opinion's "major premise," id., is dictum.

59421 U.S. at 834 n.2 (Rehnquist, J., dissenting).

${ }^{60}$ See Rahmani v. Resorts Int'l Hotel, Inc., 20 F. Supp. 2d 932, 936 (E.D. Va. 1998) ("A state cannot invalidate the lawful statutes of another state or penalize activity that lawfully occurs in another state ... . [T] he Virginia General Assembly has no power to invalidate lawful gambling taking place wholly outside of Virginia."); Florida v. Friends 
to whether Justice Rehnquist and I (an odd couple, to be sure) better characterize the Bigelow majority than do Professors Rosen and Regan, I encourage interested readers to review the opinion for themselves.

It will not do, however, to spend too much time on whether in the abstract the Bigelow analysis of a quarter century ago is better characterized as holding or dictum, since for the current Supreme Court majority, even yesterday's holdings do not constitute serious obstacles to the accomplishment of today's purposes. ${ }^{61}$ For a positivist window on the precedential status of Bigelow, the best available evidence is contained in two cases the Supreme Court has handed down since my original articles were published, one of which Professor Rosen curiously ignores.

The case which Professor Rosen discusses is United States v. Edge Broadcasting $\mathrm{Co}^{6}{ }^{62}$ in which the Supreme Court upheld a federal-not a state-regulation preventing broadcasters located in states prohibiting gambling from carrying advertisements for gambling in states where it was legal. ${ }^{63}$ Professor Rosen believes that Edge Broadcasting

of Children, Inc., 653 F. Supp. 1221, 1226 (N.D. Fla. 1986) (rejecting construction of Florida statutes that would regulate Florida women who travel to Georgia to give birth and place children for adoption); Bruce Church, Inc. v. United Farm Workers of Am., 816 P.2d 919, 924-28 (Ariz. Ct. App. 1991) (rejecting efforts to sanction labor organization for extraterritorial boycotts which were legal where they occurred); see also Am. Libraries Ass'n v. Pataki, 969 F. Supp. 160, 169 (S.D.N.Y. 1997) (considering New York's attempt to regulate transmission of obscene materials to minors over the Internet "an unconstitutional projection of New York law into conduct that occurs wholly outside New York").

${ }^{61}$ Compare Guardians Ass'n v. Civil Serv. Comm'n of New York, 463 U.S. 582, 59495 (1983) (upholding private cause of action for Title VI disparate impact violation), and Lau v. Nichols, 414 U.S. 563, 566-69 (1974) (granting relief under Title VI for disparate impact discrimination), with Alexander v. Sandoval, 532 U.S. 275 (2001) (holding that there is no private cause of action for violation of Title VI disparate impact regulations); compare City of Los Angeles v. Lyons, 461 U.S: 95, 105-10 (1983) (holding threat of future application of lethal chokeholds did not constitute irreparable injury), with Bush v. Gore, 531 U.S. 1046, 1047 (2000) (Scalia, J., concurring) (asserting that threat of bad public relations for presidential candidate constituted irreparable injury); compare Pennsylvania v. Union Gas Co., 491 U.S. 1, 5 (1989) (holding that Congress could authorize damage actions against states under the Commerce Clause), with Seminole Tribe v. Florida, 517 U.S. 44, 66 (1996) (overruling Union Gas); compare Maine v. Thiboutot, 448 U.S. 1, 9 n.7 (1980) (stating that the Eleventh Amendment does not, by its terms, apply to actions in state court), with Alden v. Maine, 527 U.S. 706, 736 (1999) (rejecting Thiboutot's reading of the Eleventh Amendment and the text of Constitution). To be sure, Bigelow itself was none too deferential to the precedent of Valentine v. Chrestensen, 316 U.S. 52 (1942). See Bigelow, 421 U.S. at 819-20 (doubting the vitality and applicability of Valentine).

${ }^{62} 509$ U.S. 418 (1993).

${ }^{63} I d$. at 436 . 
repudiates the territorialist premises of Bigelow. ${ }^{64}$

If so, the Court proceeds in a most oblique fashion. The Supreme Court in Edge Broadcasting recognized the "congressional policy of balancing the interests of lottery and nonlottery States" ${ }^{\$ 5}$ as sufficient to sustain against First Amendment challenge federal regulations barring advertisements of Virginia lotteries by interstate broadcasters located in North Carolina (which bars lotteries) ${ }^{66}$ But this conclusion does not implicate the question of whether North Carolina itself may prosecute its citizens for playing the Virginia lottery.

Congress's regulatory authority, unlike that of the states, extends to the entire country. As a matter of federal policy under the Commerce Clause, if Congress wanted to encourage North Carolina residents to gamble in Virginia, wholly in defiance of North Carolina's policy, or if, conversely, it sought to suppress interstate gambling by Virginia residents despite Virginia's enthusiasm, it would have been equally empowered to do so. ${ }^{67}$ These are wholly federal matters, going to the proper exercise of federal authority over the channels of interstate commerce and the federal desire to achieve balance between competing state regimes.

The federal interest invoked in Edge Broadcasting was not a "derivative" one as Professor Rosen asserts. ${ }^{68}$ North Carolina itself has an "interest" sufficient to seek to prohibit gambling on its own territory and to seek to dissuade its residents from gambling in neighboring Virginia; Edge Broadcasting recognizes the separate and distinct power of the federal government to regulate the message disseminated by an in-

\footnotetext{
${ }^{64}$ Rosen, Extraterritoriality, supra note 1, at 894-95.

${ }^{65} 509$ U.S. at 428 (emphasis added).

${ }^{66}$ Id. at $427-36$.

${ }^{67}$ As the Court explained in Edge Broadcasting:
}

Congress might have continued to ban all radio or television lottery advertisements, even by stations in States that have legalized lotteries. This it did not do. Neither did it permit stations such as Edge, located in a nonlottery State, to carry lottery ads if their signals reached into a State that sponsors lotteries; similarly, it did not forbid stations in a lottery State such as Virginia from carrying lottery ads if their signals reached into an adjoining State such as North Carolina where lotteries were illegal. Id. at 428.

${ }^{68}$ Rosen, Extraterritoriality, supra note 1, at 879. Justice Stevens' dissent does characterize the interest as "derivative." Edge Broadcasting, 509 U.S. at 437 (Stevens, J., dissenting). But Justice Stevens immediately goes on to state: "Of course, North Carolina law does not, and, presumably, could not, bar its citizens from traveling across the state line and participating in the Virginia lottery." Id. at $437 \mathrm{n} .1$. It hardly seems sporting to choose one piece of dictum in a dissent while ignoring its immediate neighbor. 
terstate broadcaster on North Carolina's soil. But the case gives North Carolina no authority to prosecute its residents for disregarding its norms within a sister state where gambling is legal, or to prosecute the broadcaster itself. Indeed, the Court's understanding of the federal interest in Edge Broadcasting seems to be predicated on a territorialist account of state sovereignty. The federal interest approved was not primarily in preventing North Carolinians from obtaining the broadcast information in question, but in assuring that North Carolina's authority over the acts of broadcasters within its own territory was not compromised. $^{69}$ When the Supreme Court finally addressed federal efforts to shore up local moralisms extraterritorially by preventing broadcasters in states where gambling was legal from conveying information to listeners in states where gambling was illegal, it invalidated them. ${ }^{70}$ This is not a strong line of authority for extraterritorial

\section{${ }^{69}$ The Court stated:}

[T] o prevent Virginia's lottery policy from dictating what stations in a neighboring State may air, .... advances the governmental interest in enforcing the restriction in nonlottery States, while not interfering with the policy of lottery States like Virginia. We think this would be the case even if it were true, which it is not, that applying the general statutory restriction to Edge, in isolation, would no more than marginally insulate the North Carolinians in the North Carolina counties served by Edge from hearing lottery ads.

Id. at 429-30. The Court also noted the federal government's ability generally to accommodate states with differing policies:

Edge has chosen to transmit from a location near the border between two jurisdictions with different rules, and rests its case on the spillover from the jurisdiction across the border. Were we to adopt Edge's approach, we would treat a station that is close to the line as if it were on the other side of it, effectively extending the legal regime of Virginia inside North Carolina.

Id. at 435-36.

${ }^{70}$ See Greater New Orleans Broad. Ass'n, Inc. v. United States (“GNOBA"), 527 U.S. 173, 176 (1999) (holding that federal prohibitions on "broadcast advertising of lotteries and casino gambling ... may not be applied to advertising of private casino gambling that are broadcast by radio or television stations located ... where such gambling is legal"). In characterizing Edge Broadcasting, the GNOBA Court noted that "in Edge we identified the federal interest furthered by $\$ 1304$ 's partial broadcast ban as the "congressional policy of balancing the interests of lottery and nonlottery States." Id. at 187 (quoting Edge Broadcasting, 509 U.S. at 428). The opinion continued:

As we stated in Edge: "[A]pplying the restriction to a broadcaster such as [respondent] directly advances the governmental interest in enforcing the restriction in nonlottery States, while not interfering with the policies of lottery States like Virginia.... [W] judge the validity of the restriction in this case by the relation it bears to the general problem of accommodating the policies of both lottery and nonlottery States."

Id. at 194-95 n.8 (alterations in original) (quoting Edge Broadcasting, 509 U.S. at 42930). The Court continued quoting from Edge Broadcasting: "Instead of favoring either the lottery or the nonlottery State, Congress opted to' accommodate the policies of both; and it was ' $[t]$ his congressional policy of balancing the interests of lottery and 
moralism.

Professor Rosen's account of current precedent fails entirely to mention the more recent decision of $B M W$ of North America $v$. Gore, ${ }^{71}$ in which the Court reviewed the award of a $\$ 2$ million punitive damage judgment levied against BMW by an Alabama court on the basis of a failure to disclose defects in a car that damaged the Alabama consumer by $\$ 4,000 .^{72}$ In the course of discussing the plaintiff's claim that the punitive damage judgment was justified by the aggregate evil of BMW's similar conduct in other states, the majority opinion took the position that because the conduct in question was in fact legal in the sister states where it occurred, it would be a violation of basic canons of constitutional federalism for Alabama to seek to "impose its own policy choice on neighboring states." ${ }^{73}$ Alabama, according to the Supreme Court majority, may not "impose sanctions on BMW in order to deter conduct that is lawful in other jurisdictions." ${ }^{74}$ The Court quoted from Bigelow the proposition that a "State does not acquire power or supervision over the internal affairs of another State merely because the welfare and health of its own citizens may be affected when they travel to that State.",75

I do not wish to overplay Gore. The case was decided by a vote of five to four. It referred to Alabama's effort to punish the extraterritorial activities of a foreign corporation, and so is not direct authority regarding the question that divides Professor Rosen and me. And, as Justice Scalia's dissent points out, the discussion of Bigelow occurs in the course of considering a theory that was in fact not relied upon by the Alabama Supreme Court. ${ }^{76}$ Notwithstanding these qualifications, it does appear that at least the five Justices who subscribe to the Gore majority do not regard the discussion in Bigelow as dictum, and continue to regard efforts by restrictive states to interfere with activities in

nonlottery States' that was 'the substantial governmental interest that satisfie[d] Central Hudson." Id. at $195 \mathrm{n} .8$ (alteration in original) (quoting Edge Broadcasting, 509 U.S. at 428).

717 U.S. 559 (1996).

${ }^{72}$ At trial, \$4 million in punitive damages were awarded; the Alabama Supreme Court reduced the award to $\$ 2$ million, finding that to be a "constitutionally reasonable" amount. Id. at 565-67.

${ }^{73} I d$. at $571,568-74$.

${ }^{74}$ Id. at 573 .

${ }_{75} I d$. at 571 n.16 (quoting Bigelow, 421 U.S. at 824).

${ }^{76}$ See id. at 604 (Scalia, J., dissenting) ("[T] he Alabama Supreme Court-whether it was constitutionally required to or not-'expressly disclaimed any reliance on acts that occurred in other jurisdictions." (quoting id. at 567)). 
permissive states with constitutional suspicion, a suspicion that lower courts would be well advised to share.

I must acknowledge now, as I acknowledged earlier, that the Court's articulated due process limits on the assertion of jurisdiction in civil cases have evolved during the twentieth century into a multifactor balancing approach. At least in the civil area, a state's effort to apply its own law must be based on "'a significant contact ... creating state interests, such that choice of its law is neither arbitrary nor fundamentally unfair." ${ }^{78}$ The evaluation of "unfairness" may apparently be informed by "the tradition in place when the constitutional provision was adopted" or "subsequent practice, ${ }^{, 79}$ and even after the New Deal revolution, cases still reflect judicial skepticism about the propriety of wholly extraterritorial regulation. ${ }^{80}$ In light of this evolution and the other relevant precedent, the position I articulated almost a

${ }^{77}$ This suspicion is heightened by a series of cases with which Professor Rosen declines to come to grips. In Law of Choice, supra note 2, at $477 \mathrm{n} .83$, I discuss Robinson v. California:

[I]n Robinson v. California, 370 U.S. 660, 665-66 (1962), reh'g denied, 371

U.S. 905 (1965), the Court took as given the constraint that California could punish legitimately only for the actual use of narcotics "within the state." In Robinson, although the evidence clearly demonstrated the recent use of narcotics, the jury did not necessarily find use within California. The court, therefore, treated the punishment as resting impermissibly on status, rather than conduct.

Professor Rosen ignores Robinson.

In a series of tax cases, which I discussed in Whoever Treasures Freedom, supra note 2, at 934-35, the Court suggests that due process requires that the effort to impose obligations must be predicated on "a connection to the activity itself, rather than a connection only to the actor," Allied-Signal, Inc. v. Dir., Div. of Taxation, 504 U.S. 768, 778 (1992). See also, e.g., Nat'l Geographic Soc'y v. Cal. Bd. of Equalization, 430 U.S. 551, $555-59$ (1977) (considering whether National Geographic's activities in California were extensive enough to establish the requisite "nexus" with the state for imposition of a sales tax); Am. Oil Co. v. Neill, 380 U.S. 451, 458 (1965) (requiring "'nexus' between the taxing state and the taxpayer" as the "prerequisite on state power to tax"); Treichler v. Wisconsin, 338 U.S. 251, 256 (1949) (disallowing a state inheritance tax on property located outside the state); Frick v. Pennsylvania, 268 U.S. 473, 476 (1925) (describing as "limited" the "power of each of the States to reach by taxation tangible personalty physically beyond its boundaries."). Professor Rosen does not address these cases.

${ }^{78}$ Phillips Petroleum Co. v. Shutts, 472 U.S. 797, 818 (1985) (quoting Allstate Ins. Co. v. Hague, 449 U.S. 302,313 (1981)).

${ }^{79}$ Sun Oil Co. v. Wortman, 486 U.S. 717, 730 (1988).

${ }^{80}$ See FTC v. Travelers Health Ass'n, 362 U.S. 293, 302 (1960) (expressing belief that Nebraska's power to regulate extraterritorial activity of a Nebraska corporation might be constitutionally limited); $c f$. State Bd. of Ins. v. Todd Shipyards Corp., 370 U.S. 451, 455 (1962) (holding that Allgeyer principle incorporated into McCarranFerguson Act limited state regulation of insurance). 


\section{decade ago thus still seems to be a fair account of the caselaw:}

[T] he extent of Bigelow's continued vitality ... turn[s] on the level of "significance" the Court is willing to accord to the state "interest" offered as justification for the efforts to prevent or punish extraterritorial abortions [and mutatis mutandis, other controversial activities]. The interests must be such that the application of home-state law is "neither arbitrary nor fundamentally unfair." ...

If the interest the Court recognizes in regulating abortion is primarily the interest in preventing the woman from engaging in what is regarded by her home state as an immoral act, then the "unfairness" of punishing an act approved by the jurisdiction in which it occurs might well raise sufficient due process concerns to invalidate prosecutorial efforts.

\section{B. Commerce Clause}

Professor Rosen acknowledges that the Supreme Court has regularly determined that the Commerce Clause precludes states from regulating extraterritorially. ${ }^{82}$ As I pointed out in my earlier article, this is not a recent innovation. ${ }^{83}$ Nonetheless, Professor Rosen undertakes to "[a]nalyze[] more closely" the Commerce Clause doctrine with an eye to limiting its impact on the capacity of states to control

${ }^{81}$ Kreimer, Law of Choice, supra note 2, at 478.

82 Rosen, Extraterritoriality, supra note 1, at 919-20; see also, e.g., Healy v. Beer Inst., 491 U.S. 324, 336 (1989) ("[T] he 'Commerce Clause . . precludes the application of a state statute to commerce that takes place wholly outside of the State's borders, whether or not the commerce has effects within the State." (second alteration in original) (quoting Edgar v. MITE Corp., 457 U.S. 624, 642-43 (1982) (plurality opinion))); id. at $336 \mathrm{n} .13$ ("[A]ny attempt "directly" to assert extraterritorial jurisdiction over persons or property... exceed[s] the inherent limits of the State's power." (quoting Edgar, 457 U.S. at 643)); id. at 336 ("[A] statute that directly controls commerce occurring wholly outside the boundaries of a State exceeds the inherent limits of the enacting State's authority and is invalid regardless of whether the statute's extraterritorial reach was intended by the legislature."); Baldwin v. G.A.F. Seelig, Inc., 294 U.S. 511, 521 (1935) (accepting that given the constraints of the Commerce Clause, "New York has no power to project its legislation into Vermont by regulating the price to be paid in that state for milk acquired there").

${ }^{83}$ See, e.g., Am. Express Co. v. Iowa, 196 U.S. 133, 143-44 (1905) ("To sustain ... the ruling of the court below would require us to decide that the law of lowa operated in another State so as to invalidate a lawful contract as to interstate commerce made in such other State . . . "); Bowman v. Chi. \& N.W. Ry. Co., 125 U.S. 465,498 (1888) (striking down state prohibition on importation of liquor because " $[\mathrm{i}] \mathrm{t}$ is not an exercise of the jurisdiction of the State over persons and property within its limits ... [but] is an attempt to exert that jurisdiction over persons and property within the limits of other States"); see also W. Union Tel. Co. v. Brown, 234 U.S. 542, 547 (1914) (unanimous decision) (Holmes, J.) (holding that statute imposing tort liability for negligent delivery of telegram outside of state territory violates the Commerce Clause). 
the actions of their own citizens beyond their borders. ${ }^{84}$

$\mathrm{He}$ begins by observing that the Commerce Clause limits only state regulations of commerce. With this point, I have no quarrel; it is an observation grounded in the constitutional text, and in recent years the Supreme Court has recast its jurisprudence to emphasize that not every activity should be characterized as "commercial." But quite a large number of morally controversial activities-the purchase of marijuana, gambling, assisted suicide, and abortions immediately come to mind-do involve sales of goods or services, which even under the new dispensation of the United States $v$. Lopez ${ }^{85}$ and United States v. Morrison ${ }^{86}$ majorities fall squarely within the Federal Commerce Clause. $^{87}$

Perhaps realizing that this limit does not carve out a great deal of territory, Professor Rosen undertakes to construct two doctrinal innovations in order to blunt the caselaw's established hostility to extraterritorial state regulations of commerce.

First, he maintains, in the absence of any direct support in precedent, that the prohibition of extraterritorial regulations applies only to "protectionist" regulations, not to "health and safety" regulations.

${ }^{84}$ Rosen, Extraterritoriality, supra note 1, at 920.

${ }^{85} 514$ U.S. 549 (1995).

${ }^{86} 529$ U.S. 598 (2000).

${ }^{87}$ See, e.g., United States v. Gregg, 226 F.3d 253, 254 (3d Cir. 2000) (upholding Freedom of Access to Clinic Entrances Act as exercise of commerce power); United States v. Hart, 212 F.3d 1067, 1074 (8th Cir. 2000) (same); United States v. Weslin, 156 F.3d 292, 296 (2d Cir. 1998), cert. denied, 525 U.S. 1071 (1999) (same). In addition, the Supreme Court is on record as accepting the proposition that interstate travel by individuals, even for noneconomic purposes, is "commerce" in the relevant sense. See Edwards v. California, 314 U.S. 160, 172 (1941) ("[I]t is settled beyond question that the transportation of persons is 'commerce' within the meaning of [the Commerce Clause]."); Caminetti v. United States, 242 U.S. 470, 471 (1917) (upholding statute prohibiting interstate transportation of women for any "immoral purpose," regardless of commercial gain, against Commerce Clause challenge).

${ }^{88}$ Rosen, Extraterritoriality, supra note 1, at 922 . I am gratified that Professor Rosen is a careful enough scholar to note that $I$ had suggested that a distinction between "protectionist" and "non-protectionist" extraterritorial regulations might be molded out of current doctrine. See id. at 925 n.295 (citing Kreimer, Choice of Law, supra note 2, at 496). I fear, however, that Professor Rosen has mistaken what I characterized as a "modification" of "soft" Commerce Clause doctrine, Kreimer, Choice of Law, supra note 2, at 496, for a "strong argument," Rosen, Extraterritoriality, supra note 1, at 922.

The primary case Professor Rosen cites for his analysis, Head $v$. New Mexico Board of Examiners, 374 U.S. 424 (1963), seems an odd source from which to mine dicta, for it was a case of wholly domestic conduct. Head upheld an order by a New Mexico court enjoining a New Mexico newspaper and radio station "from accepting or publishing within the State of New Mexico advertising of any nature from Abner Roberts which quotes prices or terms on eyeglasses," on the basis of a statute "applicable alike to "any 
These are categories of formidable obscurity, for one person's public welfare is another person's protectionism. ${ }^{89}$ Thus, one might quite sensibly understand an effort by Texas to protect against the corrosive "third party effects" of extraterritorial sexual experimentation by its residents as an attempt to prevent the importation of the memories of morally problematic extraterritorial experiences. This seems as "protectionist" a goal as the effort to exclude unclean waste or unclean migrants. ${ }^{90}$ Thus far, the Court has not limited the reach of its Commerce Clause protection against extraterritorial regulation in health and safety cases, and it should not do so. Equally important, cases which uphold "health and safety" justifications in other Commerce Clause contexts do not rely on "morals," which seem to be the key "third party effects" on which Professor Rosen relies.

Second, Professor Rosen suggests that the bar against extraterritorial regulation is inapplicable to efforts by states to regulate their own citizens. In this, Professor Rosen not only travels beyond precedent but also directly contradicts it. As he recognizes, Baldwin v. G.A.F. Seelig, Inc., ${ }^{91}$ the leading case on the Commerce Clause strictures against extraterritorial regulation, invalidated an effort by the state of

person' within the State of New Mexico." Id. at 427, 429 (emphasis added). The Court held that although the prospective advertiser and some of the audience were Texas residents, "as applied here to prevent the publication in New Mexico of the proscribed price advertising," the statute imposed no unconstitutional burden on interstate commerce. Id. at 429 (emphasis added). Justice Douglas' language regarding the police power was simply not directed to the question of extraterritorial regulation.

${ }^{89}$ Thus, in Baldwin v. G.A.F. Seelig, Inc., the state of New York argued unsuccessfully that "[p]rice security . . . is only a special form of sanitary security; the economic motive is secondary and subordinate; the state intervenes to make its inhabitants healthy, and not to make them rich." 294 U.S. 511, 523 (1935).

${ }^{90}$ Compare this view to Edwards v. Califormia, in which the State argued unsuccessfully for limits on immigration:

A social problem in the South and Southwest for over half a century, the 'poor white' tenants and share croppers, following reduction of cotton planting, droughts and adverse conditions for small-scale farming, swarmed into California.... They avoid our cities and even our towns by crowding together, in the open country and in camps, under living conditions shocking both as to sanitation and social environment. Underfed for many generations, they bring with them the various nutritional diseases of the South. Their presence here upon public relief, with their habitual unbalanced diet and consequently lowered body resistance, means a constant threat of epidemics. Venereal diseases and tuberculosis are common with them, and are on the increase. The increase of rape and incest are readily traceable to the crowded conditions in which these people are forced to live. Petty crime among them has featured the criminal calendars of every community into which they have moved.

314 U.S. 160, 167-68 (1941).

${ }_{91} 294$ U.S. 511 (1935). 
New York to prevent what the court characterized as "a milk dealer in the city of New York" from purchasing low-priced milk in Vermont. ${ }^{92}$ Although Professor Rosen asserts that the citizenship of Seelig is "unclear," the Supreme Court record contains Seelig's complaint, which affirmatively pleads that the plaintiff is both a New York corporation and a New York "citizen and resident." ${ }^{\text {,93 }}$ The sources of the lack of clarity Professor Rosen perceives remain somewhat mysterious. Similarly, in Schwegmann Brothers Giant Super Markets v. Louisiana Milk Commission, ${ }^{94}$ the Court summarily affirmed an injunction against Louisiana's efforts to preclude a Louisiana partnership from purchasing ice cream in Tennessee for subsequent sale in Louisiana at less than Louisiana's fixed wholesale price. Most recently, Healy $v$. Beer Institute invalidated Connecticut's regulation of beer brewers and distributors on the ground that it effectively controlled the prices at which those distributors sold beer in neighboring states. ${ }^{95}$ The majority noted in passing that the statute regulated both out-of-state distributors doing business in Connecticut and "Connecticut brewers who sell both in Connecticut and in at least one border state," without indicating the least inclination to uphold the statute with respect to Connecticut corporations. ${ }^{96}$ It is hardly surprising, therefore, that the Seventh Circuit, in the case that Professor Rosen criticizes, ${ }^{97}$ failed to appreciate what Professor Rosen regards as the crucial significance of state citizenship for Commerce Clause analysis.

There is a final peculiarity in Professor Rosen's view of the Commerce Clause. If a state's extraterritorial control of its citizens for ideological reasons is immunized to Commerce Clause review, the road to economic Balkanization is paved with good-or at least perfectionist-intentions. While Vermont cannot impose a \$10-percamper tax on camps that serve campers who are residents of Maine,

92 Id. at 518.

${ }^{93}$ Transcript of Record at 3, Baldwin v. G.A.F. Seelig, Inc., 294 U.S. 511 (1935) (No. 604), microformed on U.S. Supreme Court Records and Briefs (Microcard Editions, Inc.) (Complaint I 1). For what it is worth, the corporation from which the plaintiff purchased the milk in question was also a New York corporation. Id. (Complaint II 8).

${ }_{94} 416$ U.S. 922 (1974), summarily affg, 365 F. Supp. 1144, 1152-56 (M.D. La. 1973).

491 U.S. 324, 324-25 (1989).

${ }^{96}$ Id. at 341; see also United States Brewers Ass'n v. Healy, 692 F.2d 275, 276 (2d Cir. 1982) (invalidating earlier Connecticut regulation applicable to both local and foreign importers), aff d without opinion, 464 U.S. 909 ' (1983).

${ }_{97}$ Dean Foods Co. v. Brancel, 187 F.3d 609, 616, 620 (7th Cir. 1999) (holding Wisconsin milk-pricing regulations unconstitutional on extraterritoriality grounds by reasoning that the state may not regulate commerce "wholly outside its borders"). 
Maine-on the theory that exposure of impressionable children to the same-sex unions prevalent in Vermont is pernicious-can impose a $\$ 10$-per-camper fine on those same campers for use of the same camps. Although the impact on free trade among the states is identical, under Professor Rosen's analysis, the latter approach is permissible. Worse, Vermont would be free to impose reciprocal sanctions on its own residents for doing business in Maine-a state whose moral bankruptcy under Vermont's political values is revealed by the anticamper tax. And if Vermont were unable to prohibit the sale of lowcost Maine milk within its boundaries, it would be free to seek Maine legislation prohibiting residents of Maine from selling milk in Vermont, perhaps in exchange for Vermont legislation barring Vermont residents from using Maine's waste dumps.

Whether the protections of the Dormant Commerce Clause are based in the economic benefits of free trade, or a vision of the political benefits of a common national market, they can be threatened no less from the sending than from the receiving end of the interstate transaction. To prohibit citizens beyond a state's borders from participating in commerce is precisely the sort of barrier to internal commercial union that the Commerce Clause was designed to prevent.

\section{Privileges and Immunities and Travel}

American liberty entails mobility; our ability to pull up stakes and move on stands at the core of our self-image, and our geographical interpenetration has forged the United States into a single nation. Founded by immigrants, expanded by migration, nurtured by movement, rights of mobility have been a staple of American liberty. ${ }^{98}$ Yet such rights do not appear in the constitutional text, and one might have expected that a Court increasingly drawn to textualist analysis of individual rights would abandon them.

In Saenz $v$. Roe, decided after my prior articles, six members of the Court nonetheless reiterated a vision of constitutional structure predicated on free mobility of citizens among states. ${ }^{99}$ For individuals, the Saenz majority proclaimed that "'[i]t is a privilege of citizenship of the

${ }^{98}$ I discuss these matters in Kreimer, Federalism and Freedom, supra note 2; Kreimer, Whoever Treasures Freedom, supra note 2, at 914-17; and Kreimer, Law of Choice, supra note 2 , at 500-08.

${ }^{99}$ See 526 U.S. 489, 489-91 (1999) (characterizing discriminatory classifications as violative of a citizen's right to be treated equally in her new state of residence). 
United States, protected from state abridgement, to enter any State of the Union, either for temporary sojourn or for the establishment of permanent residence." ${ }^{100}$ The Court reaffirmed a right to travel "not found in the text of the Constitution," yet "firmly embedded in our jurisprudence;" "the right of 'free ingress and regress to and from' neighboring states" that was expressly mentioned in the text of the Articles of Confederation may simply have been "conceived from the beginning to be a necessary concomitant of the stronger Union the Constitution created." ${ }^{101}$ According to the Court, travel brings constitutionally protected opportunities:

[B]y virtue of a person's state citizenship, a citizen of one State who travels in other States, intending to return home at the end of his journey, is entitled to enjoy the "Privileges and Immunities of Citizens in the several States" that he visits. This provision removes "from the citizens of each State the disabilities of alienage in the other States. ${ }^{.102}$

States, conversely, are bound to accept visitors and migrants by a constitution "framed upon the theory that the peoples of the several states must sink or swim together, and that in the long-run prosperity and salvation are in union and not division." 109

Professor Rosen and I disagree on exactly what this vision implies for efforts by states to interfere with their citizens who seek to take advantage of legal opportunities provided by other states. In earlier articles, Professor Rosen acknowledged that states cannot prevent their citizens from emigrating permanently to a more congenial regime as a way of escaping moralistic demands. ${ }^{104}$ I agree; Saenz $v$. Roe holds quite squarely that the Citizenship Clause of the Fourteenth Amendment embodies a right of each American "'of his own volition [to] become a citizen of any State of the Union by a bona fide residence therein," and this right binds both state and federal governments. ${ }^{105}$

${ }^{100}$ Id. at 511 n.27 (quoting Edwards v. California, 314 U.S. 160, 183 (1941) (Jackson, J., concurring)).

${ }^{101}$ Id. at 498, 501 (quoting Shapiro v. Thompson, 394 U.S. 618, 643 (1969); United States v. Guest, 383 U.S. 745, 758 (1966)).

${ }^{102}$ Id. at 501-02 (footnote omitted) (quoting Paul v. Virginia, 75 U.S. 168, 180 (1869)).

${ }^{103}$ Id. at 511 (quoting Baldwin v. G.A.F. Seelig, Inc., 294 U.S. 511, 523 (1935)).

${ }^{104}$ See Rosen, Outer Limits, supra note 1, at 1093-106 (arguing that people will move to localities that match their moral outlook if such localities are well-ordered and that "exit" rights are necessary to legitimacy of the system); Mark D. Rosen, Multiple Authoritative Interpreters of Quasi-Constitutional Federal Law: Of Tribal Courts and the Indian Civil Rights Act, 69 FORDHAM L. REV. 479, 504 (2000) ("The second requirement is that those within the perfectionist enclave be able to 'exit' it.").

${ }^{105} 526$ U.S. at 503 (quoting The Slaughter-House Cases, 83 U.S. (16 Wall.) 36, 80 
In his current article, Professor Rosen states that "[a] Home State cannot interfere with its citizens' rights to leave for the purpose of visiting another State nor prevent its citizens from returning." ${ }^{106}$ Again, I concur; a line of cases beginning with Crandall $v$. Nevada ${ }^{107}$ testifies to this proposition. The question that divides us is what these travelers may do during their visits.

\section{Privileges and Immunities}

The first line of analysis begins with a specific constitutional text. The Privileges and Immunities Clause of Article IV (also referred to as the "Comity Clause"), as the Supreme Court reminded us in Saenz $v$. Roe, "removes . . . 'the disabilities of alienage" from state citizens entering other states in the Union and gives them "equality of privilege with citizens of [the host] States." ${ }^{108}$ Under the clause a citizen of one state is "entitled" while traveling to the "Privileges and Immunities" of a citizen of the state she visits.

On its face, this regime implies that where a "host" state provides its citizens with the "privilege" of engaging in a particular contested activity, visiting citizens of other states are "entitled" to engage in the same activity. Thus, in Doe v. Bolton, the Court invalidated Georgia's attempt to deny women who resided in other states the opportunity to obtain abortions available to Georgians. ${ }^{110}$ According to the Court, "[j] ust as the Privileges and Immunities Clause ... protects persons who enter other States to ply their trade ... so must it protect persons who enter Georgia seeking the medical services that are available there."111 I have previously argued that this protection also precludes efforts by travelers' home states to interfere with their efforts to take advantage of this constitutional entitlement. If Georgia cannot prevent residents of Florida from making use of Georgia's abortion services by prosecuting the Georgia doctors who perform the abortions, Florida cannot make those same services unavailable by prosecuting the Florida residents for using those services upon their return home. ${ }^{112}$

(1873))

${ }^{106}$ Rosen, Extraterritoriality, supra note 1, at 913-14.

10773 U.S. (6 Wall.) 35, 49 (1868).

${ }^{108} 526$ U.S. at 501-02 (quoting Paul v. Virginia, 75 U.S. 168, 180 (1869)).

${ }^{109}$ U.S. CONST. art. IV, $\S 2$, cl. 1 .

${ }^{110} 410$ U.S. 179, 200 (1973).

${ }^{111} I d$.

${ }^{112}$ This argument shares a structure with the reasoning in Crandall $v$. Nevada that 
Professor Rosen raises three objections to this reasoning. First, he notes that as the Supreme Court has interpreted the Privileges and Immunities Clause, it does not extend to all activities in which a visitor might wish to engage. ${ }^{113}$ Professor Rosen maintains that "[n]one of the peripatetic citizens' activities" he considers would fall within the protection of the Privileges and Immunities Clause. ${ }^{114}$ This objection is simply not well founded.

While the Court has imposed limits on the scope of the Comity Clause, Professor Rosen sees the glass as three-quarters empty when in fact it is ninety-nine percent full. As Professor Rosen points out, the Supreme Court has held that the opportunity to hunt elk for recreation can be denied to out-of-state residents because it is not sufficiently "'basic to the maintenance or well-being of the Union"" to constitute a privilege or immunity of citizenship. ${ }^{115}$ But this holding is unique in recent cases. The Court has found that the opportunity to practice law, the opportunity to fish for shrimp, the opportunity to deduct alimony payments from state income taxes, and the opportunity to be employed on public works projects are all "sufficiently basic" to qualify as "privileges and immunities."116 Modern cases have reaf-

the citizen's right to petition the national government implies that a state cannot prevent its citizen from leaving for that purpose. 73 U.S. (6 Wall.) 35, 39-40 (1867).

There have not been many test cases for this proposition, since states have in general not attempted to export their morality, but the decision of the New York judiciary in the midst of the stresses leading up to the Civil War is indicative. Despite the state's antislavery commitments, an effort to prosecute New York residents who sold a free black man from New York in Washington, D.C., was held to violate Article IV, Section 2:

The Constitution was intended to be binding, as it regards the rights of the citizens of the several states, upon the people of the whole union. It was never intended that a legislature should violate state comity or national rights, as the section in question does, by assuming to punish as a felony a sale of property in a state or district where the right exists by the laws of the locality to make such a sale.

People v. Merrill, 2 Parker's Crim. Cas. 590 (1855); see State v. Cutshall, 15 S.E. 261, 264 (1892) ("The attempt to evade the organic law by making the coming into this State (after committing an offense in another) a crime is too palpable, in view of the admitted fact that the Constitution ... gives to citizens of all the states the immunities and privileges of its own citizens ....").

${ }_{13}$ Rosen, Extraterritoriality, supra note 1, at 898-899.

114 Id. at 899.

${ }^{115}$ Id. (quoting Baldwin v. Fish \& Game Comm'n, 436 U.S. 371, 388 (1978)).

116 See Lunding v. N.Y. Tax Appeals Tribunal, 522 U.S. 287 (1998) (alimony deduction); Supreme Court v. Friedman, 487 U.S. 59 (1988) (practice of law); Supreme Court v. Piper, 470 U.S. 274 (1985) (practice of law); Hicklin v. Orbeck, 437 U.S. 518 (1978) (employment on public works project); Toomer v. Witsell, 334 U.S. 385 (1948) (fishing for shrimp). 


\title{
firmed Justice Bushrod Washington's canonical account of the scope of the relevant privileges and immunities in Corfield $v$. Coryell:
}

\begin{abstract}
They may, however, be all comprehended under the following general heads: Protection by the government; the enjoyment of life and liberty, with the right to acquire and possess property of every kind, and to pursue and obtain happiness and safety; subject nevertheless to such restraints as the government may justly prescribe for the general good of the whole. The right of a citizen of one state to pass through, or to reside in any other state, for purposes of trade, agriculture, professional pursuits, or otherwise; to claim the benefit of the writ of habeas corpus; to institute and maintain actions of any kind in the courts of the state; to take, hold and dispose of property, either real or personal; and an exemption from higher taxes or impositions than are paid by the other citizens of the state; may be mentioned as some of the particular privileges and immunities of citizens, which are clearly embraced by the general description of privileges deemed to be fundamental ....
\end{abstract}

It may be that some peripheral activities fall outside of the protection of the Privileges and Immunities Clause, but in important cases of moral dissensus, the efforts of host states to impose limits on visitors of which they relieve their own residents would fall under the clause. ${ }^{118}$

Second, Professor Rosen maintains that the Privileges and Immunities Clause imposes limits only on a state's treatment of foreign citizens. ${ }^{119}$ Thus, he takes the position that even if a person with AIDS

${ }^{117} 6$ F. Cas. 546, 551-52 (C.C.E.D. Pa. 1823) (No. 3230), quoted with approval in Baldwin v. Fish \& Game Comm'n, 436 U.S. 371, 385, 387 (1978); see Piper, 470 U.S. at $281 \mathrm{n} .10$ ("[W]e have noted that those privileges on Justice Washington's list would still be protected by the [Privileges and Immunities] Clause."); Austin v. New Hampshire, 420 U.S. 656, 661 (1975) (describing Corfield as "the first, and long the leading, explication of the [Privileges and Immunities] Clause").

Another general account is contained in Paulv. Virginia:

[It is] the object of the clause in question to place the citizens of each State upon the same footing with citizens of other States, so far as the advantages resulting from citizenship in those States are concerned. It relieves them from the disabilities of alienage in other States... it insures to them in other States the same freedom possessed by the citizens of those States in the acquisition and enjoyment of property and in the pursuit of happiness ....

75 U.S. 168, 180 (1868), quoted with approval in Hicklin v. Orbeck, 437 U.S. 518, 523-24 (1978), and Baldwin v. Fish \& Game Comm'n, 436 U.S. 371, 380 (1978).

${ }_{118}$ I am somewhat mystified at how Professor Rosen can maintain that the opportunity for minors to obtain an abortion would not be considered a "privilege" or "immunity," Rosen, Extraterritoriality, supra note 1, at 899, when Doe v. Bolton, 410 U.S. 179, 200 (1973), cited with approval only last year in Saenz $v$. Roe, invalidated Georgia's prohibition of nonresident abortions as a violation of the Comity Clause.

${ }^{119}$ See Rosen, Extraterritoriality, supra note 1, at 900 ("The Privileges and Immunities Clause has long been understood as having created limitations on Host States with respect to citizens visiting from other states, but at no point has it been understood to 
from Utah may be "entitled" under the clause to the "privilege" of using medical marijuana in California to alleviate his symptoms, Utah may nonetheless punish him for exercising his constitutional entitlement.

Such a result has no basis in the constitutional text, which seems to guarantee the "entitlement" of the state citizen against interference from any quarter; the other provisions of Article IV certainly can be asserted by a citizen against her state of origin. Allowing a home state to destroy what a host state is required to give seems an odd way of assuring citizens the "same freedom possessed by citizens" of the states they visit. ${ }^{120}$

I concede, as I did in my earlier work, that Professor Rosen can rely on a line of Supreme Court cases with language stating that citizens cannot invoke the protections of the Comity Clause against their own states. ${ }^{121}$ These cases have dealt entirely with actions by states against their own citizens triggered by the citizens' local actions. They involve no interaction with other states and thus do not raise the question of what status an effort to interfere with an Article IV "entitlement" to engage in out-of-state conduct would have. Still, I must acknowledge that a vindication of a citizen's rights in such a situation would be required to break some new ground. ${ }^{122}$

limit a state's regulatory powers over its own citizens.").

${ }^{120}$ Indeed, even if the clause is directed entirely to the dangers of a state's treatment of out-of-state citizens, an interpretation which left a state's treatment of its own citizens unconstrained would allow states in partnership to manipulate the protections of the clause out of existence. If New Hampshire sought to eliminate the competition of Vermont lawyers, it could induce Vermont to prohibit its citizens from practicing law in New Hampshire-perhaps in exchange for prohibiting New Hampshire residents from practicing law in Vermont, thereby gutting Piper. So, too, if one took seriously the claim that only out-of-staters could invoke the clause, Vermont could presumably punish its own citizens for doing business with New Hampshire attorneys it sought to exclude.

${ }_{121}$ There is one Supreme Court case that relies on this proposition for its holding: Bradwell v. Illinois, 83 U.S. 130, 138 (1872). Professor Rosen's assertion that United Building $\mathcal{E}$ Construction Trades Council v. Mayor of Camden, 465 U.S. 208 (1984), and Zobel v. Williams, 457 U.S. 55 (1982), relied on the inapplicability of the Privileges and Immunities Clause, Rosen, Extraterritoriality, supra note 1, at 901-02, is mysterious. Zobel invalidated the statute at issue, 457 U.S. at 65 ; therefore, the Court could not have relied on the validity of the statute under Article IV. Camden upheld a challenge by an organization whose members included out-of-state residents against a motion to dismiss, 465 U.S. at 223; the outcome could not have been premised on a claim that a challenge by local residents would fail.

${ }^{122}$ A second approach leading to the same conclusion also has no determinative precedent either way. The Privileges and Immunities Clause of the Fourteenth Amendment precludes a citizen's home state from "abridging their rights of national 
Finally, Professor Rosen invokes the proposition that the Privileges and Immunities Clause, as currently interpreted, is not "absolute" and maintains that the effort to prevent citizens from avoiding the legal regime of their home state should be viewed as a sufficient basis for either the home state or the host state to prevent conduct in which the traveler would otherwise be entitled to engage under the Comity Clause. $^{124}$

Here, again, we function largely without direct precedent. Professor Rosen acknowledges that in Austin v. New Hampshire, the Supreme Court stated that "the constitutionality of one State's statutes affecting nonresidents [cannot] depend upon the present configuration of the statutes of another State."125 Austin quoted Travis v. Yale $\mathcal{E}$ Towne Manufacturing Co. to emphasize that the entitlements under the Comity Clause accrue to citizens, rather than the states where they reside: “'A State may not barter away the right, conferred upon its citizens by the Constitution of the United States, to enjoy the privileges and immunities of citizens when they go into other States." Rosen maintains that these cases are distinguishable because they involve "self-interested," "beggar-thy-neighbor" statutes rather than ef-

citizenship." Saenz v. Roe, 526 U.S. 489, 503 n.15 (1999). Since the "entitlement" to engage in contested activities on a basis of equality with foreign citizens in a foreign state arises from the national Constitution, it is a right of national citizenship. Therefore, regardless of whether this right can be asserted directly against the home state under Article IV, the Privileges and Immunities Clause of the Fourteenth Amendment precludes the home state from seeking to interfere with a citizen who takes advantage of this right.

Colgate v. Harvey, 296 U.S. 404 (1935), adopted a similar theory in striking down a discriminatory state tax applied to a citizen's out-of-state bank deposits under the Fourteenth Amendment's Privileges and Immunities Clause, as an interference with rights of national citizenship. Id. at 433. Colgate was overruled in Madden v. Kentucky on the ground that "[a]n interpretation of the privileges and immunities clause which restricts the power of the states to manage their own fiscal affairs is a matter of gravest concern." 309 U.S. 83, 93 (1940). The approach I suggest, by contrast, imports no untoward interventions on state fiscal policy. Indeed, the tax at issue in Madden would now be impermissible as a burden on interstate commerce, see, e.g., Fulton Corp. v. Faulkner, 516 U.S. 325, 346 (1996) (finding North Carolina's intangibles tax violated the Commerce Clause where it was facially discriminatory against interstate commerce), and probably violates the Equal Protection Clause as well. See Metro. Life Ins. Co. v. Ward, 470 U.S. 869, 883 (1985) (finding Alabama's domestic preference tax violated the Equal Protection Clause where it promoted domestic businesses by discriminating against nonresident competitors).

${ }_{123}$ Rosen, Extraterritoriality, supra note 1, at 907.

${ }^{124}$ Id. at $907-08$.

${ }^{125} 420$ U.S. 656,668 (1975).

${ }^{126}$ Id. at 667 (quoting Travis v. Yale \& Towne Manufacturing Co., 252 U.S. 60, 82 (1920)). 
forts to give deference to the goals of neighboring states. ${ }^{127}$ From the point of view of whether the discrimination produces friction between the states, this may be relevant; when both states agree that a traveler should be unable to exercise the privileges of local citizens, no official interstate friction will result. But the Comity Clause was designed to give the people of the United States the benefits of national unity even if particular sets of states would prefer mutual insularity. ${ }^{128}$ From the point of view of the ability of traveling citizens to participate equally in the life of the states they visit, whether laws which label them as visiting aliens result from protectionism or reciprocally parochial motivations is irrelevant. The impact of separating Americans from one another by state of origin is identical, and it is the rights of the citizens that the state may not "barter away."

On the other hand, in no case that either Professor Rosen or I can identify has a court dismissed a privileges and immunities claim on the ground that the discrimination in question is necessary to prevent a citizen from avoiding the extraterritorial strictures that her home state imposes on her conduct. Professor Rosen adverts to Bradford Electric Light Co. v. Clapper, ${ }^{129}$ in which New Hampshire, in the course of a suit between a Vermont employee and a Vermont employer, applied a Vermont statute precluding recovery for an accident in New Hampshire. ${ }^{130}$ The Clapper Court's holding, however, was not based

\footnotetext{
$\because 27$ Rosen, Extraterritoriality, supra note 1, at 906.

${ }^{128}$ As Gerald Neuman explains:
}

Both the wording of the clause and its interpretation suggest as a paradigm the right of a citizen of state $A$, while physically within the borders of state $B$, to interact with citizens of state $B$ on the same legal terms as those that govern their interaction among themselves. ...

Nonresidents who are known to carry their domicile's law with them cannot participate as equals in the life of the state.

Gerald L. Neuman, Territorial Discrimination, Equal Protection, and Self-Determination, 135 U. PA. L. REV. 261, 323-24 (1987) (footnotes omitted); see also Douglas Laycock, Equal Citizens of Equal and Territorial States: The Constitutional Foundations of Choice of Law, 92 COLUM. L. REV. 249, 263-70 (1992) ("The Clause is first and foremost a national unity provision, ... . with . . the . . dual purpose of achieving national unity and preserving the states as separate polities."); Douglas Laycock, Equality and the Citizens of Sister States, 15 FLA. ST. U. L. REV. 431, 438-39 (1987) ("The "Constitution we have preserves the states as separate polities, but also federates them into the larger polity of the union."); Jonathan D. Varat, State "Citizenship" and Interstate Equality, 48 U. CHI. L. REV. 487, 518-19 (1981) ("The framers adopted the constitutional ban on state discrimination against non-residents primarily as an instrument of national unification. The nondiscrimination principles ... leave[] people free to make their home in one state without sacrificing the opportunity to share in the bounty found in others.").

${ }^{129} 286$ U.S. 145 (1932).
Id. at 157. 
on the duties of citizenship or a right to control citizens extraterritorially. The Supreme Court relied on the conduct of the parties within Vermont itself: entry into the underlying employment contract, which excluded recovery. The opinion disavowed any implication that Vermont could control the actions of its citizens extraterritorially. It emphasized:

[Vermont's] statute does not undertake to prohibit acts beyond the borders of the State. Compare Allgeyer v. Louisiana, 165 U.S. 578; Nutting v. Massachusetts, 183 U.S. 553, 557. It does not attempt to forbid or regulate subsequent modification of the Vermont contract, or the formation of subsidiary contracts, or new agreements, by the parties in other States. Compare New York Life Ins. Co. v. Head, 234 U.S. 149; New York Life Ins. Co. v. Dodge, 246 U.S. 357. It affects only the rights and liabilities of parties who by their conduct within the State have subjected themselves to its operation. As to those parties, its effect is not to create a liability for acts without the State, compare Western Union Telegraph Co. v. Brown, 234 U.S. 542, but to give rise to a defense in consequence of acts within.

The "interest" of the home state in extraterritorial moralism is in excluding the experiences buried in their citizens' memories when they return to their residence. It is far from clear that this interest is one that is "substantial."

\section{The Right to Travel and Its Reasons}

If we focus on constitutional structure, the result is similar. The Court in Saenz reaffirmed the proposition that "the nature of our

${ }^{131}$ Id. at 157 n.7. Professor Rosen's reliance on Sosna v. Iowa, 419 U.S. 393 (1975), is equally tenuous. He focuses on one of three grounds that together the opinion characterizes as a "reasonable" justification for the statute in question. See Rosen, Extraterritoriality, supra note 1, at 908-09 (discussing Sosna in the context of "a Host State's desire not to interfere in the policy of a sister state"); see also Sosna, 419 U.S. at 406-07 (finding Iowa durational residency requirement for divorce reasonably justified on grounds of the state's interests in (1) requiring those seeking a divorce to have a "modicum of attachment to the State," (2) insulating its divorce decrees from collateral attack, and (3) not becoming "a divorce mill for unhappy spouses"). As he acknowledges, this alone raises questions about whether deference to a home state's policy alone would constitute a "substantial" justification required by Comity Clause analysis. Rosen, Extraterritoriality, supra note 1, at 908-09. More importantly, the Sosna Court's acknowledgement of a desire to avoid "officious intermeddling in matters in which another State has a paramount interest," 419 U.S. at 407, arises out of the fact that a divorce decree has direct impact on the legal rights not only of the person seeking the decree, but of that person's spouse, who may be a resident of another state. An interest in avoiding legal disruption of family relations in other states or avoiding destruction of legal relations established by other states is quite different from an interest in allowing another state to spare its citizens the discomfort of knowing that one of their compatriots violated their moral code extraterritorially. 
Federal Union and our constitutional concepts of personal liberty unite to require that all citizens be free to travel throughout the length and breadth of our land uninhibited by statutes, rules or regulations which unreasonably burden or restrict this movement." ${ }^{132}$ This freedom to "travel throughout the length and breadth of our land" is not important because it allows citizens to observe new landscapes, but because the right to travel contributes to our constitutional structure by providing the opportunity for interaction among fellow Americans. It is by intercourse as equals that the country is knit together across parochial boundaries, and it is by sharing the experience of others that our personal horizons are broadened and our liberty reaffirmed. If our bodies can move among states, but our freedom of action is tied to our place of origin, then the "right to travel" becomes a hollow shell.

Under Professor Rosen's scheme, the right to travel is vulnerable to exactly this evisceration. Imagine that New York comes under the sway of a majority of radical vegetarians. Not content with punishing the consumption of meat and cognizant of the importance of norms and social pressure in shaping behavior, the state legislature adopts a code which bars "giving aid and comfort to carnivores," prohibiting any citizen of the state from doing business with, providing anything of value to, associating socially with, or approaching closer than ten feet to any person who consumes meat. ${ }^{133}$ If Bill Clinton decides to travel to Texas, he can do so under Professor Rosen's approach. But when Clinton arrives in Texas, not only will he be liable to punishment in New York if he eats a locally legal Big Mac, but he also will be barred from any effective interaction with the people or society around him. He might as well stay in Chappaqua. As Professor Tribe put the point:

The conclusion that a state's legal system must not hobble a citizen as she travels from state to state follows from a conception of interstate mobility that entails something more than just a change of scenery. If each state could decide for itself, possibly with some measure of congres-

192526 U.S. 489, 499 (1999) (quoting Shapiro v. Thompson, 394 U.S. 618, 629 (1969)).

${ }^{133}$ Professor Rosen acknowledges that "shunning" is a standard method of control among perfectionist communities. Rosen, Outer Limits, supra note 1, at 1144. The prohibitions on business dealings and transfers of funds are economic regulations subject only to rational basis scrutiny. With regard to the prohibition of social association, compare City of Dallas v. Stanglin, 490 U.S. 19, $23-25$ (1989), with City of Chicago v. Morales, 527 U.S. 41, 52-55 (1999). On the prohibition on approaching others, see Hill $v$. Colorado, 530 U.S. 703 (2000). 
sional authorization, how much of its legal system its citizens would have to carry around on their backs while seeking to take advantage of the legal environments of other states, then the right to choose which state to enter for any purpose lawful in that state would amount to nothing more than the right to have the physical environment of the states of one's choosing pass before one's eyes in a kind of virtual reality arcade while one remained strapped at all times in a legally fixed and closed environment. Surely, however, more than that is involved in the right of interstate mobility that follows from the basic structure of our federal Union. ${ }^{194}$

To be sure, not every perfectionist state will isolate its citizens so fully, but it is the true believers who will be tempted most by Professor Rosen's invitation.

Professor Rosen would doubtless respond to this analysis, as he does in the body of his article, with the accusation that it is grounded in my "bald" assertions, ${ }^{135}$ and it is true that no case explicitly prohibits the type of state action that Professor Rosen invites. This is not because the courts approve of such action, but rather because it does not occur. Although they are willing to protect their local interests against concrete threats, American states acknowledge the sovereignty of their fellow members of the Union within their respective borders, and have not engaged in the extraterritorial projection of perfectionist morality. In my view, this practice appropriately reflects the nature of our constitutional culture.

\section{PERSPECTIVES FROM PHILOSOPHY}

\section{A. Reading Rawls}

In an innovative approach, Professor Rosen maintains that a "Rawlsian" analysis mandates that states be able to enforce their perfectionist norms against extraterritorial conduct by their citizens. ${ }^{136}$ I

${ }^{134}$ Laurence H. Tribe, Saenz Sans Prophecy: Does the Privileges or Immunities Revival Portend the Future-Or Reveal the Structure of the Present?, 113 HARV. L. REV. 110, 152 (1999).

${ }^{135}$ See Rosen, Extraterritoriality, supra note 1, at 913 ("The nature of our national identity is deeply contested, and bald appeals to 'national identity' of the sort made by Professor Kreimer cannot decide the question at issue."); id. at $913 \mathrm{n} .240$ ("[Professor Kreimer] . . baldly asserts that the clause "imparts to individual American citizens the freedom that accompanies national citizenship." (quoting Kreimer, Whoever Treasures Freedom, supra note 2, at 920)). This is a particularly difficult criticism for me as middle age advances and my hairline recedes.

${ }^{136}$ See Rosen, Extraterritoriality, supra note 1, at 888 ("From a Rawlsian perspective, a federal system in which states may extraterritorially regulate their traveling citizens is 
must confess the argument seems to me less than overwhelming.

Initially, one might question why in construing the mandates of American federalism, we should rely on a Harvard philosopher of the late twentieth century. Locke or Hume might be relevant to original understandings, but I have been unable to identify a single citation to Professor Rawls in the Supreme Court's jurisprudence or the relevant constitutional documents. There is, moreover, some peculiarity in the effort to invoke Rawls as a basis for a paternalist/perfectionist claim of the sort that Professor Rosen seeks to advance. As Professor Rosen acknowledges in an earlier article, "Rawls expressly states that he believes that political perfectionists cannot be accommodated under political liberalism." ${ }^{137}$ Professor Rosen seeks to maintain, however, that the nature of American federalism makes a liberal duty what Rawls denies is a liberal option.

It seems to me that in a number of areas Professor Rosen misapplies Rawls' philosophical apparatus. ${ }^{138}$ But Professor Rosen need not

the fair and just political structure.").

${ }^{137}$ Rosen, Outer Limits, supra note 1, at 1106 . Rawls flatly rejects the possibility of perfectionist claims as the basis of public decisions, at least where they interfere with the liberties of individuals. JOHN RAWLS, THEORY OF JUSTICE 327-30 (1971) [hereinafter RAWLS, THEORY OF JUSTICE].

${ }^{138}$ For example, Professor Rosen seeks to assimilate the capacity to regulate moralistically to the "basic liberty of conscience" to which Rawls accords lexical priority in a fairly just state. It is not entirely clear that the right to regulate others is, in Rawls' view, a "liberty," a term that is generally identified with the opportunity to accomplish one's own ends, not the opportunity to impose one's ends on others. In Outer Limits, supra note 1, Professor Rosen argues that the right to regulate is a "pre-condition" for a perfectionist life, but this is a misuse of the Rawlsian scheme; Rawls clearly limits the right to the preconditions necessary for a liberty to "equal value" of political rights. See JOHN RAWLS, POLITICAL LIBERALISM 356-58 (1993) [hereinafter RAWLS, POLITICAL LIBERALISM] (allowing for regulation of political speech only where it is "rationally designed to achieve the fair value of the political liberties"). Perhaps Professor Rosen believes that the right to control others' actions is a part of the "political liberty" of selfgovernance to which Rawls does in fact allude.

But if the right to regulate behavior $Z$ can be a matter of conscience and basic liberty, then presumably the right (or obligation) to engage in behavior $Z$ can equally be a matter of conscience and basic liberty. What we have then, in Rawlsian terms, is a conflict between two "basic liberties." One way of limiting such conflicts, for Rawls, is the stipulation it is only over its "central range" that each liberty must be "fully adequate." See id. at 295-97 ("[B]asic liberties can be made compatible with one another, at least in their central range of application."); JOHN RAWLS, JUSTICE AS FAIRNESS, A RESTATEMENT $\$ \$ 32.1-32.2$ (Erin Kelly ed., 2001) [hereinafter RAWLS, JUSTICE AS FAIRNESS] ("So long as what we may call 'the central range of application' of each basic liberty is secured, the two principles are fulfilled."). Professor Rosen does not seek to identify the "central range" of the "liberties" he is seeking to protect.

As we have seen, the norm in American society is a conception of domestic regulatory power; in general, citizens who seek to drive over the speed limit, to gamble, or to 
make a technical philosophical argument. His position is "Rawlsian" primarily to the extent that he utilizes Rawls' heuristic device of the original position. The core of his argument, as I understand it, is an intuitive claim that because territorial limitations preclude the full achievement of a class of political ideals in which some people may believe deeply, such a structure would not be chosen behind a veil of ignorance by individuals who do not know whether they themselves might be adherents of such ideals, and is, therefore, unfair.

The first premise of Professor Rosen's argument has some merit. Some citizens cannot fully achieve their conscientious goals without exerting state authority to assure that all members of their locality abide by those goals. If states are territorially limited and residents can temporarily escape moralistic regulation by traveling to more libertarian states, then those who desire as a matter of conscience to live in a society in which everyone else always acts in accordance with their chosen norm (let us call it ' $Z$ ') can accomplish the goal fully only if they can persuade all of the others in the society to live in that fashion. Even if I can ban all local "adult entertainment," my burning moral desire that no member of my community be polluted by pornography will fail if my fellows still can read dirty books across the border. Territorial limitations mean that true believers can achieve $Z$ compliance with respect to actions within the state, but lose the possibility of coercing their fellows extraterritorially. They risk having to live in proximity to those who act differently outside of the state and therefore will find it harder to pursue their ideals. ${ }^{139}$

But Professor Rosen's deduction from this proposition neglects another set of considerations that would be relevant behind a Rawlsian veil of ignorance. In addition to Z-opponents, a society may con-

read locally obscene material all have the capacity to avoid domestic regulations by extraterritorial excursions. As a matter of observation, these limitations have not undercut the core of self-government. Since Rawls looks to political culture to identify the "central range" of basic liberties (including, presumably, the liberty of selfgovernance), Rawls, POLITICAL Liberalism, supra, at 346 , it would seem that the "central range" of moralistic self-governance in American society is generally territorial. Indeed, for Rawls, the liberty of self-government in general appears to be territorial. See John Rawls, The Law of Peoples $38-39$ (1999) (“[A]n important role of a people's government ... is to be the representative and effective agent of a people as they take responsibility for their territory.").

${ }^{139}$ Note that the position for which Professor Rosen contends here is not simply, as he articulated the matter in Outer Limits, that "political perfectionists who satisfy specific criteria to govern themselves" and to "associate as they believe necessary for their self-development," Rosen, Outer Limits, supra note 1, at 1061, 1091, but rather that political perfectionists should have the right to take control of the machinery of an entire state and to impose their chosen morality on all of its residents extraterritorially. 
tain Zenthusiasts, and in the original position one cannot know which group will predominate. If Z-enthusiasts prove to be the majority, they would be in a position to mandate the practice of $Z^{140}$ Thus, a $Z$ opponent in the original position choosing between my position of territorialism (or "soft pluralism") and Professor Rosen's position of extraterritorialism (or "hard pluralism") confronts the following decision structure:

1) Under territorialism, either Zopponents or Zenthusiasts can escape temporarily to the sanctuary of other states leaving open possible outcomes:

1a) A ban on Zpractice with the possibility of escape for Z enthusiasts; or

1b) A mandate of Zpractice with the possibility of escape for $Z$ opponents.

2) Under extraterritorialism, neither Zopponents nor Z-enthusiasts can escape, leaving open possible outcomes:

2a) A ban on Zpractice with no possibility of escape for Z enthusiasts, short of emigration; or

2b) A mandate of Zpractice with no possibility of escape for Zopponents, short of emigration.

A Zopponent would presumably rank the results: $2 a>1 a>2 b>1 b$. The possibility of inescapably imposing a $Z$ ban would be the best outcome; the possibility of inescapably suffering a $Z$ mandate would be the worst. If Rawls is correct in his argument that under conditions of radical uncertainty the parties would adopt a maximin strategy, ${ }^{141}$ even if one knew that one was a Zopponent, one would opt for territorialism behind the veil. The outcome a Zopponent would most want to avoid is the possibility of being forced to engage in $Z$ herself. ${ }^{142}$

140 In many cases, as for example in the case of abortion, Zenthusiasts will be content to allow, rather than mandate, the contested practice, but there will be other situations, like the choice between open and closed adoptions, where enthusiasts will impose their choices on their fellows.

${ }^{141}$ RAWLS, JUSTICE AS FAIRNESS, supra note 138 , $\S \S$ 28.1-28.2; RAWLS, THEORY OF JUSTICE, supra note 137, at 152-54.

${ }^{142}$ I must admit that a properly creative political theorist could generate a set of conscientious preferences in which evils of the possibility of Zpractice by others extraterritorially dominates the possibility of being required to engage in $Z$ oneself. See, e.g., Amartya Sen, The Impossibility of a Paretian Liberal, 78 J. POL. ECON. 152, 155 (1970) ("Person 1, who is prude, prefers most that no one reads [Lady Chatterly's Lover] but given the choice between [himself or another] reading it, he would prefer that he read it himself rather than exposing gullible Mr. 2 to the influences of Lawrence."). Prude, believing himself immune to the evils of pornography, would be indifferent between outcomes $2 b$ (where both Prude and Lewd could be required to read pornography in their home state) and $1 b$ (same situation, but Prude can temporarily escape to Utah). 
Equally important, in the original position, one must contend with the possibility that one will end up being a Zenthusiast. If states can impose their moralisms extraterritorially, then those who conscientiously pursue norm $Z$ but would like to live in the state because it has characteristics $A$ through $Y$ (hearth, home, job, and friends), will be forced to sacrifice either $A$ through $Y$ or $Z$.

Behind the Rawlsian veil, just as I cannot know whether I am a liberal or a perfectionist, I cannot know whether I will represent a person whose system of meaning forbids or requires a particular contested practice. The appropriate Rawlsian question is whether I would be more willing to risk living in a polity where my ideals are incompletely realized-because some can evade them-or a polity in which my ideals are entirely suppressed and can be realized only by leaving my home, my job, and my friends entirely. I would submit that a decision-making procedure that seeks to avoid the worst outcome would seek to avoid the second risk.

Indeed, this seems to be the burden of the text upon which Professor Rosen relies. He quotes Rawls for the proposition that since the parties "do not know whether the beliefs espoused by the persons they represent [are] a majority or a minority view," they cannot "'take chances by permitting a lesser liberty of conscience to minority relig-

But he would prefer an outcome that could forbid Lewd to read porn in Babylon, NY (2a) to one in which Lewd could escape (1a).

Similarly, since September 11 hijacker Mohammed Atta preferred death and the possibility of the triumph of his preferred norms to life and the existence of a society whose commitments he found repulsive, one might infer that he would be equally repelled by the existence of such a society within which he was free to pursue his own goals and one in which he was himself forced to participate in the activities he found conscientiously distasteful. After all, he could always escape the imposition by suicide.

But these examples have the smell of the lamp about them; they are neither plausible guides for public policy nor likely in a country with America's constitutional commitments to constitute the moral bases on which lives are constructed.

As Ned Diver pointed out to me in comments on this paper:

[In Rawlsian terms] these cases are exceptions to the general rule that the ability to pursue one's own conception of the good is more important than being able to enforce that view on others. Since these examples are exceptions, they don't have a real effect on the rationality of the decision behind the veil of ignorance.... [T] he idea that people should, in general, be free to pursue their own conceptions of the good ... requires that limitations be placed on interference with others' [pursuing] their conceptions of the good. The creative exceptions don't change the fact that this is the best general bet from the original position....

E-mail from Edward Diver, Doctoral Candidate, Department of Philosophy, University of Pennsylvania, to Seth F. Kreimer, Professor of Law, University of Pennsylvania Law School (Nov. 7, 2001, 11:00:12 EST) (on file with author). 
ions, say, on the possibility that those they represent espouse a majority or dominant religion and will therefore have an even greater liberty." "149 If this is true for conscientious beliefs about religion, it would seem to be equally true for conscientious beliefs about abortion, medical marijuana, or assisted suicide.

It will not do to say that the right to impose moralisms that Professor Rosen espouses is limited to areas which are not themselves recognized as constitutionally protected. Behind the Rawlsian veil, one cannot be assured that in cases of conflict, one's own conscientious commitments will be recognized by the courts. A structure that preserves the opportunity to pursue conscientious commitments where they are recognized by any state in the union would seem to be the structure that avoids "taking chances with liberty."

\section{B. "Evasion" and Moral Obligation}

Professor Rosen's denigration of the process of taking advantage of neighboring liberties as "travel-evasion" seems to be rooted in a sense that there is something disreputable or immoral about the enterprise. In Professor Rosen's view, residents owe their states obedience no matter where their actions occur and the effort to take advantage of other legal regimes is an improper evasion of this obligation. ${ }^{145}$ But if the opportunities provided by a federal structure are legitimate, taking advantage of them is no more an "evasion" of legitimate obligations than claiming a legitimate child-care deduction is an "evasion" of the income tax. Thus, in evaluating Professor Rosen's criticism, one must reflect on exactly how far a moral duty of obedience to law extends and in doing so, it is worth engaging in a somewhat wider scope of philosophical exploration than does Professor Rosen.

One possible ground of obligation is consent. Certainly, John Locke argued that:

${ }^{143}$ Rosen, Extraterritoriality, supra note 1, at 888 (alteration in original) (quoting RAWLS, POLITICAL LIBERALISM, supra note 138, at 26).

${ }^{144}$ A final thought: for Rawls himself, at least in his later work, a key goal of the system is the establishment of "social cooperation on the basis of mutual respect," RAWLS, POLITICAL. LibERAliSM, supra note 138, at 337-38, an ideal that would seem to be better furthered by forcing moralistic majorities to rely on persuasion for the full accomplishment of their ideals.

${ }^{145}$ Rosen, Extraterritoriality, supra note 1, at 883 ("Since consent to abide by laws that are lawfully enacted, and to incur the consequences if one does not, is a cornerstone of citizenship, it is fair for a state to expect that its citizens will obey legitimately enacted state laws ...."). 
[E]very man that hath any possessions or enjoyment of any part of the dominions of any government doth thereby give his tacit consent and is as far forth obliged to obedience to the laws of that government, during such enjoyment, as anyone under it; whether this his possession be of land to him and his heirs for ever, or a lodging only for a week, or whether it be barely travelling freely on the highway; and, in effect, it reaches as far as the very being of anyone within the territories of that government. $^{14 i}$

But tacit consent seems a weak basis on which to found a moral obligation to forsake our core interests. A young woman born into a household in Pennsylvania has not chosen to subject herself to a parental consent requirement for abortions, a comatose man in Wisconsin does not choose to abandon the opportunity to die with dignity, and few would say that an AIDS patient in Utah forced to choose between the only available means of avoiding suffering and abandonment of his family and friends acts immorally in seeking to avoid the choice. These are not the sort of free decisions that usually support the voluntary assumption of obligation. As Hume put the matter, "We may as well assert that a man, by remaining in a vessel, freely consents to the dominion of the master, though he was carried on board while asleep, and must leap into the ocean and perish the moment he leaves her." ${ }^{147}$ Indeed, the prospect of temporary sanctuary in other states

146 JOHN LOCKE, The Second Treatise of Civil Government, in Two TREATISES OF Government 119, 182 (Thomas I. Cook ed., Hafner Publ'g Co. 1947) (1690).

${ }^{147}$ David Hume, Of the Original Contract [hereinafter HuME, Original Contract], in Hume's MORal AND Political PHILOSOPHY 356, 363 (Henry Aiken ed., Hafner Publ'g Co. 1948) (1748). Later versions of this objection exist in the literature. See, e.g., RONALD DWORKIN, LAW's EMPIRE 192-93 ("Consent cannot be binding on people... unless it is given more freely and with more genuine alternate choice than just by declining to build a life from nothing under a foreign flag."); RUTH W. GRANT, JOHN LOCKE'S LIBERALISM 126 (1987) ("If the criteria [for what constitutes consent] are 'weak,' for example, mere residence in one's native country, then consent theory... blunts the point of the claim that no man is subject to the authority of another without his own consent."); Kent GreEnaWALT, Conflicts of LAW AND MORAlity 73 (1987) ("People stay in homelands because of language, culture, job, friends, and family; their inertia hardly indicates approval or acceptance of government and laws."); DON HERZOG, HAPPY SLAVES 183 (1989) ("Skeptical objections come fast and furious, only some of them with a nod to Hume.... Maybe [residence] signifies apathy; maybe it signifies lack of alternatives.... Subjection to the government ... might be something I'm grudgingly willing to put up with as the onerous price tag attached to staying."); DON HERZOG, Without Foundations 80 (1985) ("One can take as consent only those acts that allow ... a way of refusing consent. Therefore, if our very being within territories of the government is to count as consent, we must be allowed to leave."); GeORGe Klosko, The Principle of Fairness and Political Obligation 143 (1992) ("If consent is reduced to residence, or even to one's mere presence in the country, then voluntary consent has lost its point."); JOSEPH RAZ, MORALITY OF FREEDOM 88-94 
provided by territorial limits may constitute the only situation in which one could plausibly claim that the citizen has made a choice to bind herself to the law of her home state. It is precisely this prospect that Professor Rosen denies.

As I have previously argued, the most plausible claims for an obligation of legal obedience are based either on the Humean argument that the obligation of obedience is a crucial element of a civilized order that protects against descent into violence and mutual oppression or on the belief that moral authority of the law arises out of the obligation to fairly support reasonably just institutions of which one reaps the benefit. ${ }^{148}$ Yet neither of the arguments justifies extraterritorial obligations.

\section{Hume's claim rests on the proposition:}

$[\mathrm{M}] \mathrm{en}$ could not live at all in a society. . without laws and magistrates and judges to prevent the encroachments of the strong upon the weak, of the violent upon the just and equitable .... If the reason be asked of that obedience which we are bound to pay to government, I readily answer, because society could not otherwise subsist.

(1986) (" $[$ T $]$ he instrumental as well as non-instrumental validations of consent depend on its being freely given."); A. JOHN Simmons, MORAL Principles AND POLITICAL OBLIGATIONS (1979) ("The problem is that it is precisely the most valuable "possessions" a man has that are often tied necessarily to his country of residence and cannot be taken from it.").

${ }^{148}$ This is the source of obligation for John Rawls, of whom Professor Rosen is otherwise enamored. See RAWLS, THEORY OF JUSTICE, supra note 137, at 111-12 ("[The principle of fairness] holds that a person is required to do his part as defined by the rules of an institution when ... the institution is just ... and ... one has voluntarily accepted the benefit of the arrangement. . . All obligations arise in this way.").

${ }^{49}$ Hume, Original Contract, supra note 147, at 368. See generally id. at 359-72 (discussing practical necessity as justification for government authority); DAVID HUME, Treatise of Human Nature [hereinafter HUME, Human Nature], in HUME's MORAL AND POLITICAL PHILOSOPHY, supra note 147, at 2, 114 ("When men have once experienced the impossibility of preserving any steady order in society while every one is his own master... they naturally run into the invention of government .... [The natural supposition of obedience] of right and obligation are derived from nothing but the advantage we reap from government."); id. at 104 ("We shall quickly see how fruitless it is to ... seek in the laws of nature a stronger foundation for our political duties than interest and human conventions."); id. at 105 ("To obey the civil magistrate is requisite to preserve order and concord in society.").

The problem, as Hume conceived it, was what we would today call a prisoner's dilemma:

[Men] prefer any trivial advantage that is present to the maintenance of order in society which so much depends on the observance of justice. The consequences of every breach of equity seem to lie very remote, and are not liable to counterbalance any immediate advantage that may be reaped from it... [A]s all men are in some degree subject to the same weakness, it necessarily 
But when a citizen travels into the realm of another sovereign, obedience to the host's laws is perfectly adequate to assure "that society can subsist." 150 Likewise, the obligation to "support" just institutions does not carry any necessary implications as to the geographical scope of the duty. It is entirely consistent with the proposition that, as long as I do not actively seek to undermine the just institutions of my home state-as by committing treason or shooting a cannon into its territory or discharging noxious fumes across the border-my obligation to "support" my home institution is liquidated by my obedience to its laws within its boundaries, and my payment of taxes while I reside there. And assuming that we treat both home state and host state as "just institutions," when a Utah citizen travels to California, under this theory she is under a duty to "support" California, as well as Utah. When the laws of California soberly inform her that the opportunity to choose her reproductive future is her moral and legal right, she owes deference to its "just judgments" as well as those of her home state.

The crucial point of these analyses is that a citizen who takes advantage of the liberties of neighboring states does not evade an obligation to obey the law. Rather the obligation to obey the home state's law simply does not reach into the territory of the sister state; on her territory, there is an obligation to obey her law. Such an approach does not substitute anarchy or raw will for the rule of law, for it is only liberties that are sufficiently well grounded to command the respect of

happens that the violations of equity must become very frequent in society, and the commerce of men by that means be rendered very dangerous and uncertain.... Your example both pushes me forward in this way by imitation, and also affords me a new reason for any breach of equity by showing me that I should be the cully of my integrity if I alone should impose upon myself a severe restraint amidst the licentiousness of others.

HUME, Human Nature, supra, at 98.

The Humean consequentialist argument is approvingly rehearsed in HERzoG, WITHOUT FOUNDATIONS, supra note 147, at 180-87, sketching Hume's account of political obligation and defending it against a line of criticism. Cf. KLOSKO, supra note 147, at 93-94 (presenting problems with Hume's assessments of the benefits of justice).

${ }_{150}$ Cf. ThOMAS Hobbes, LeViathan 153-54 (Richard Tuck ed., Cambridge Univ. Press 1991) (1651) ("The obligation of subjects to the sovereign is understood to last as long, and no longer, than the power lasteth, by which he is able to protect them.... For whosoever entereth into anothers dominion, is subject to all the laws thereof, unless he have a privilege by the amity of the sovereigns."). It is true that extraterritorial actions may undermine particular policies, but in the absence of some concrete effects on the home state, they do not threaten a slide into anarchy. Indeed the fact that the United States has functioned with reasonable stability during its first $\mathbf{1 7 5}$ years under a regime that held extraterritorial moralism unambiguously unconstitutional suggests that extraterritorial moralism cannot be the sine qua non of effective polity. 
another state of the union that may be claimed in this fashion. Where the moral judgment of two sovereigns clashes, federalism leaves the citizen some opportunity to take advantage of the judgment of either.

\section{CONCLUSION}

Professor Rosen may, of course, reply to my philosophical excursus that Hume is no more determinative of constitutional analysis than is Rawls. If so, we must return to the text, history, structure, and practice of American federalism. All of these, it still seems to me, weigh heavily against the extraterritorial assertion of moralism to punish actions that take place on the soil of and with the permission of sister states. State boundaries are not mere lines on a map; they are lines in the sand. In our federal system, by stepping over those lines an American citizen may claim her freedom. 


\section{APPENDIX: STATE CONSTITUTIONAL BARS TO EXTRATERRITORIAL PROSECUTION}

Thirty-three states have constitutional provisions that require juries in criminal trials to be drawn from the geographical district in which the crime occurred:

\begin{tabular}{|c|c|}
\hline Alabama & Art. I, $\S 6$ \\
\hline Arizona & Art. II, § 24 \\
\hline Arkansas & Art. II, $\S 10$ \\
\hline Colorado & Art. II, $\S 16$ \\
\hline Florida & Art. I, $\S 16(a)$ \\
\hline Hawaii & Art. I, § 14 \\
\hline Illinois & Art. I, $\$ 8$ \\
\hline Indiana & Art. I, $\S 13$ \\
\hline Kansas & Bill of Rights, $\$ 10$ \\
\hline Kentucky & Bill of Rights, $\$ 11$ \\
\hline Louisiana & Art. I, $\S 16$ \\
\hline Maine & Art. I, $\S 6$ \\
\hline Massachusetts & Art. XIII, pt. 1 \\
\hline Minnesota & Art. I, $\S 6$ \\
\hline Mississippi & Art. III, $\S 26$ \\
\hline Missouri & Art. I, $\$ 18(a)$ \\
\hline Montana & Art. II, $\S 24$ \\
\hline Nebraska & Art. I, $\S 11$ \\
\hline New Hampshire & Art. XVII, pt. 1 \\
\hline New Mexico & Art. II, $\$ 14$ \\
\hline Ohio & Art. I, $\$ 10$ \\
\hline Oklahoma & Art. II, $\$ 20$ \\
\hline Oregon & Art. I, § 11 \\
\hline Pennsylvania & Art. I, $\S 9$ \\
\hline South Carolina & Art. I, § 11 \\
\hline South Dakota & Art. VI, $\$ 7$ \\
\hline Tennessee & Art. I, $\S 9$ \\
\hline Utah & Art. I, § 12 \\
\hline Virginia & Art. I, $\S 8$ \\
\hline Washington & Art. I, § 22 \\
\hline West Virginia & Art. III, § 14 \\
\hline Wisconsin & Art. I, $§ 7$ \\
\hline Wyoming & Art. I, $\S 10$ \\
\hline
\end{tabular}

Courts in these states have found territorial constraints in other provisions of their constitution as well. ${ }^{1}$

${ }^{\prime}$ E.g., State v. Smith, 421 N.W.2d 315 (Minn. 1988) (" $[$ A $]$ n attempt to exercise totally extraterritorial jurisdiction is contravened both by state and federal constitutional principles. Only if some part of the crime was committed within the State of Minne- 
In Maryland, whose Declaration of Rights provides "[ $t]$ hat the trial of the facts, where they arise is one of the greatest securities of the lives, liberties and estate of the People," ${ }^{2}$ the courts take the position that "'an offense against the laws of the State of Maryland is punishable only when committed within its territory. A person cannot be convicted here for crimes committed in another state." "'

In addition, I have been able to identify four other states-Idaho, Michigan, New York, and North Carolina-whose highest courts have interpreted their own constitutional conceptions of state sovereignty to preclude wholly extraterritorial prosecutions during the last quarter of the twentieth century. ${ }^{4}$ There may well be others that have escaped my research.

sota does the state have jurisdiction to punish the crime."); State v. Baldwin, 305 A.2d 555 (Me. 1973) ("'It is elementary law that the statutes of a state have no extra-territorial force, nor do its courts have any jurisdiction of offenses committed in other states or foreign countries."' (quoting State v. Stephens, 107 A. 296, 297 (Me. 1919))).

${ }^{2}$ MD. CONST. art. 20.

${ }^{3}$ Maryland v. Butler, 724 A.2d 657, 660 (Md. 1999) (quoting Bowen v. State, 111 A.2d 844, 847 (Md. 1955)).

${ }^{4}$ See State v. Cochran, 538 P.2d 791, 793 (Idaho 1975) (holding that, as a general rule, Idaho courts lack jurisdiction over criminal offenses that were not committed in the state); People v. Blume, 505 N.W.2d 843, 845 (Mich. 1993) (determining that Michigan courts do not exercise jurisdiction over crimes that occur out of state unless the act was intended to have, and actually does have, a detrimental effect within the state); People v. McLaughlin, 606 N.E.2d 1357, 1359 (N.Y. 1992) ("Jurisdiction ... is a question of the sovereign's power to prosecute and punish an accused for conduct which is allegedly criminal. Because the State only has power to enact and enforce criminal laws within its territorial borders, there can be no criminal offense unless it has territorial jurisdiction." (citation omitted)); State v. Batdorf, 238 S.E.2d 497, 502 (N.C. 1977) ("We have recognized from earliest times that the criminal jurisdiction of our courts is territorially restricted."); $c f$. State v. Wagner, 596 N.W.2d 83, 88-89 (Iowa 1999) (holding that jurisdictional provisions of Iowa's criminal code preclude wholly extraterritorial prosecution). 
* * * * * * * *

$\therefore$ 